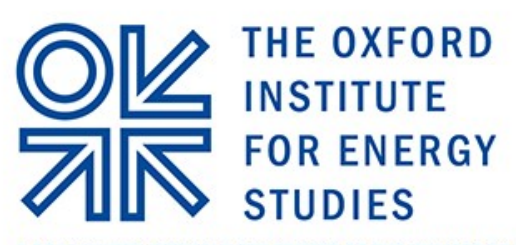

A RECOGNIZED INDEPENDENT CENTRE OF THE UNIVERSITY OF OXFORD

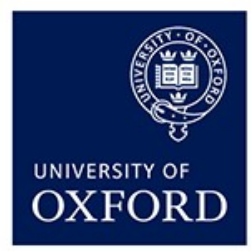

February 2014

\title{
LNG Plant Cost Escalation
}

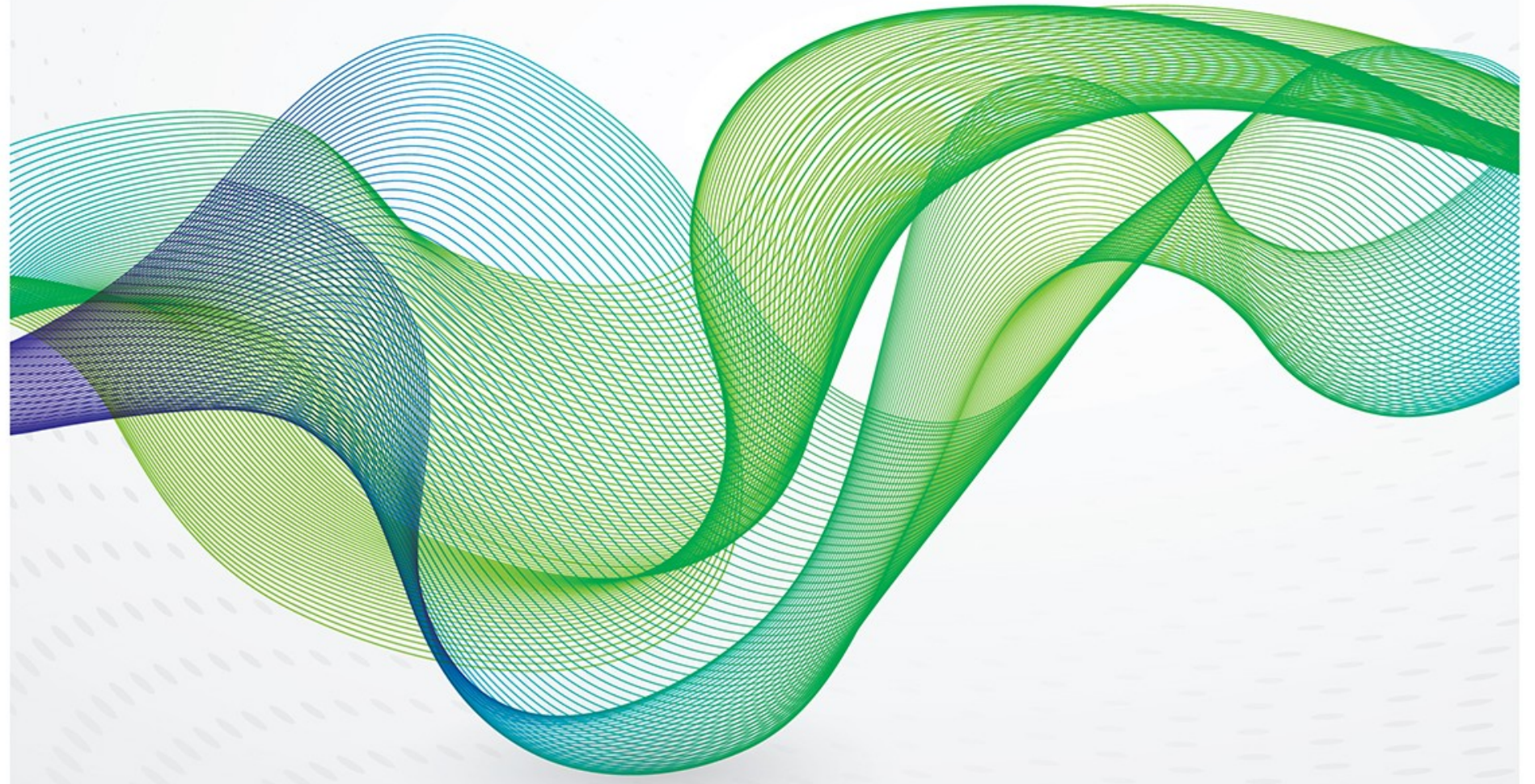

Brian Songhurst * 
The contents of this paper are the author's sole responsibility. They do not necessarily represent the views of the Oxford Institute for Energy Studies or any of its members.

Copyright $\odot 2014$

Oxford Institute for Energy Studies

(Registered Charity, No. 286084)

This publication may be reproduced in part for educational or non-profit purposes without special permission from the copyright holder, provided acknowledgment of the source is made. No use of this publication may be made for resale or for any other commercial purpose whatsoever without prior permission in writing from the Oxford Institute for Energy Studies.

ISBN 978-1-978-1-907555-94-7 


\section{Acknowledgements}

I express my gratitude to colleagues in the LNG industry working for the financial \& commercial institutions, plant owners \& operators and in the EPC contractor sector for their input and final review. I remain responsible for the conclusions and opinions expressed in this paper. 


\section{Preface}

Prior to 2000, LNG as a means of providing natural gas was mainly confined to markets lacking alternative supply options, and was elsewhere considered as a 'niche' supply source. In the early to mid-2000s this began to change as the growth in gas demand in importing regions continued and LNG supply sources such as Trinidad and Tobago and later Qatar were developed at a cost level which allowed LNG to compete in markets formerly dominated by pipeline gas. Between 2004 and 2009 the economic growth surge experienced by the BRICS and their commodity import and investment requirements served to increase the price of oil and other commodities but also the unit investment costs in capital intensive industries. These costs almost doubled in real terms during this period. On the face of it the impact on liquefaction plant costs appeared to be significantly more pronounced.

Since 2010 regional natural gas prices have diverged. US prices have been generally below $\$ 4.50 / \mathrm{mmbtu}$; European hub prices in the range $\$ 8$ to $\$ 11 / \mathrm{mmbtu}$ and Asian LNG prices (linked contractually to oil prices) have risen to a level of around $\$ 15 / \mathrm{mmbtu}$. Until recently the prevailing assumption in the oil and gas industry has been that at the post 2009 level of liquefaction costs, only Asia represents a viable market for new LNG projects. This in itself would be reason enough to undertake the research and analysis in this paper.

With the recent approval of US LNG projects, where existing re-gasification terminals are to be converted into export facilities through the incremental investment in liquefaction plant, research published by the OIES Gas Programme in 2012 described scenarios in which LNG from the US and other new or expanding supply sources might result in a world where LNG trading and arbitrage could yield sustainable hub prices (at today's development cost levels) of US: $\$ 5-6 / \mathrm{mmbtu}$; Europe $\$ 10-$ 11/mmbtu and Asian LNG \$12 - 13/mmbtu.

In such a scenario an obvious issue is the very substantial competitive advantage conferred on US energy intensive industries relative to those situated in Europe and in Asian LNG markets. In terms of $\mathrm{CO}_{2}$ emission abatement concerns, the prospects for gas in the power sector in competition with coal and in the absence of strong government policy support at such prices would appear bleak outside of North America. The key point is that the regional gas price differentials in such a scenario are directly influenced by the assumption of the continuation of today's liquefaction (and to a lesser extent shipping) costs.

In this paper Brian Songhurst assesses the reasons for the liquefaction cost level increases in the last decade by placing the available data into a framework in which an objective comparative analysis is possible. He also discusses trends in the LNG project construction and execution sector which should lead to cost reductions over time. I am grateful to Brian in the application of his considerable experience in writing this paper and also the diligence with which he undertook to gather information, views and opinions from some of the key players participating in the design, construction, operation and financing of LNG projects.

Howard Rogers

Oxford, February 2014 


\section{Contents}

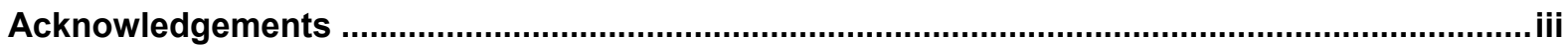

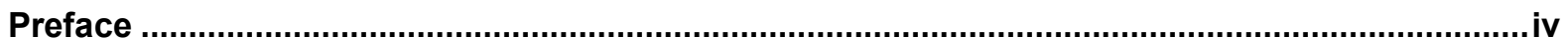

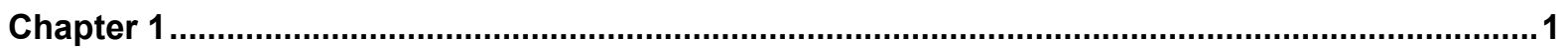

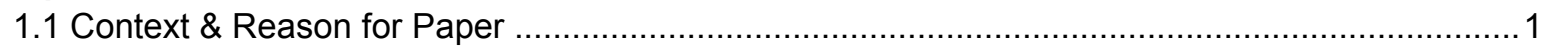

Chapter 2

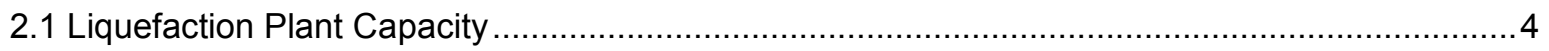

Chapter 3

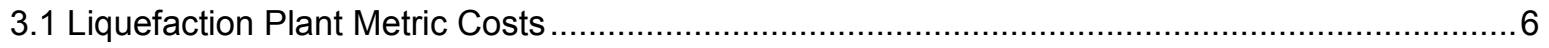

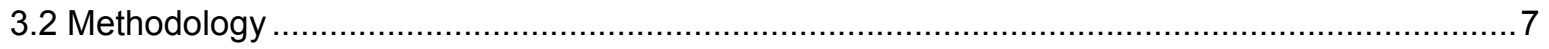

Chapter 4

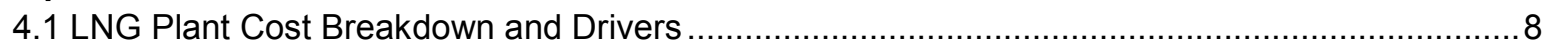

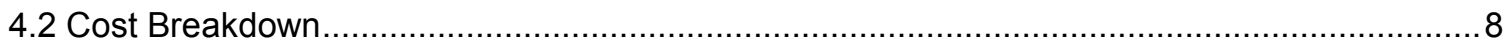

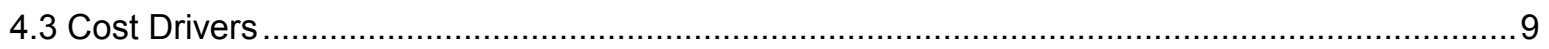

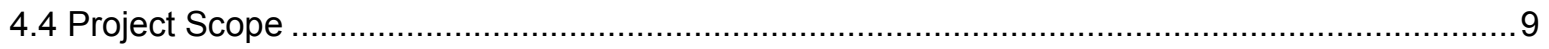

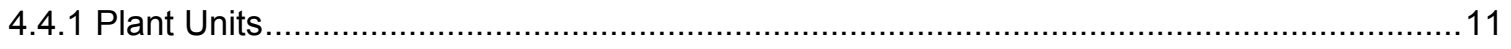

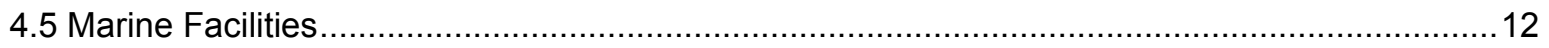

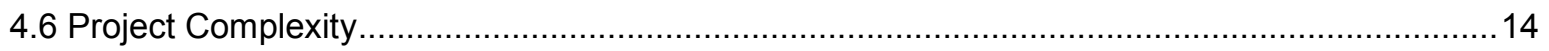

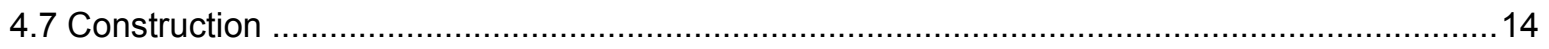

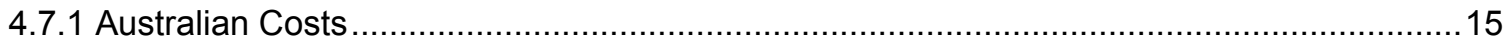

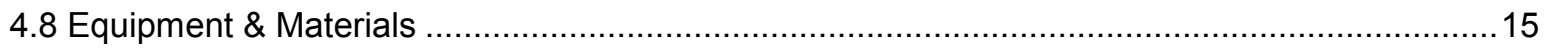

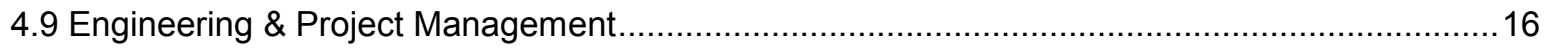

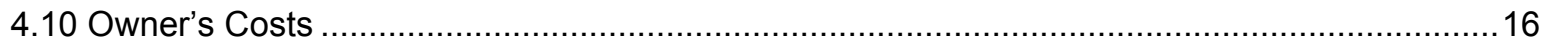

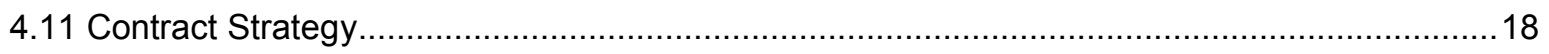

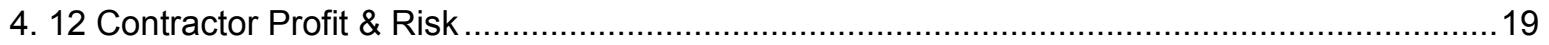

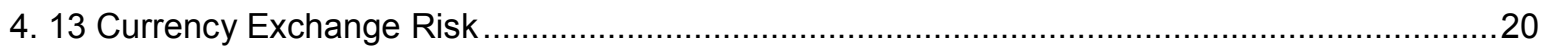

Chapter 5

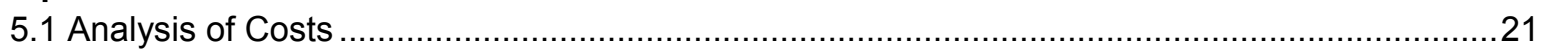

5.1.1 Plant Scope - Expansion vs. Complete Facility (Grass Roots) .......................................21

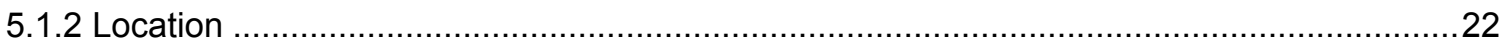

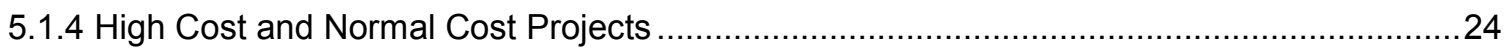

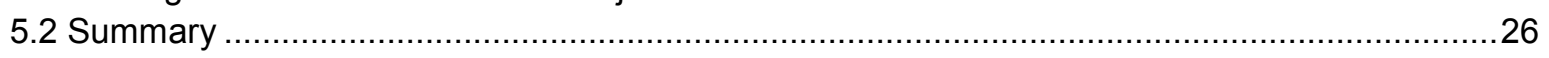

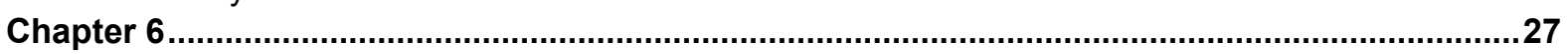

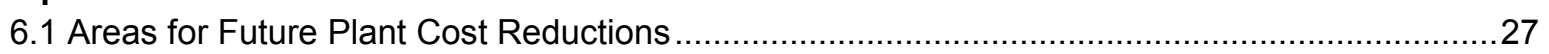

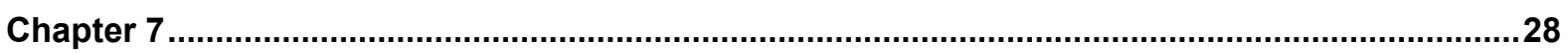

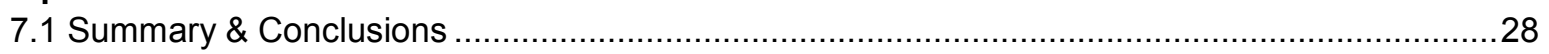

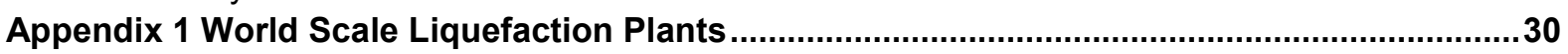

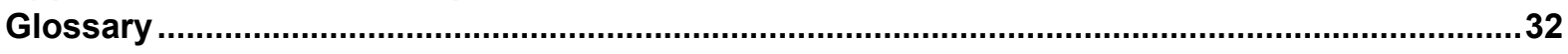

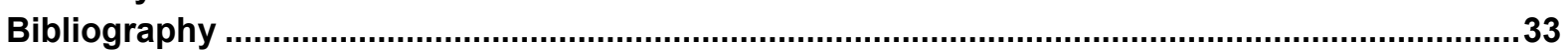




\section{Figures}

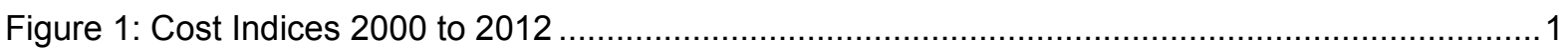

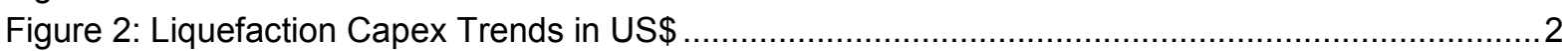

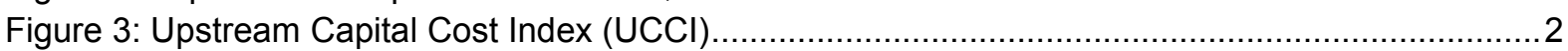

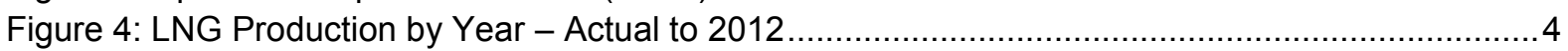

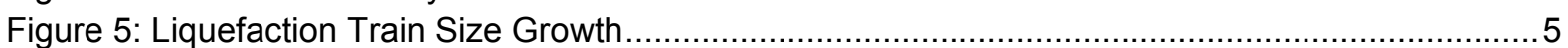

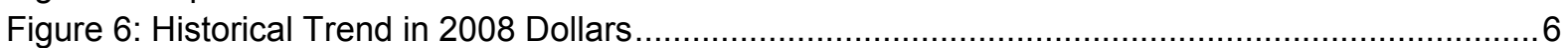

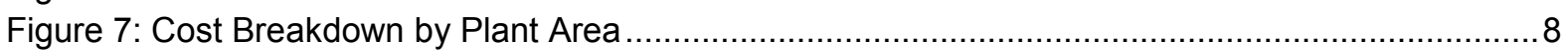

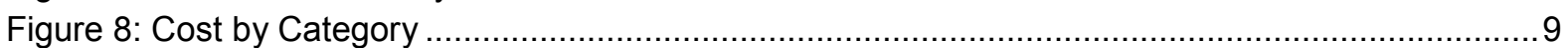

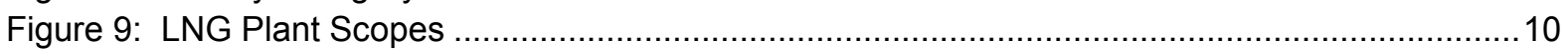

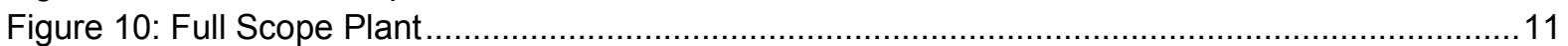

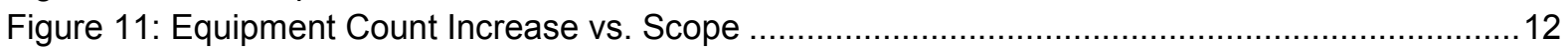

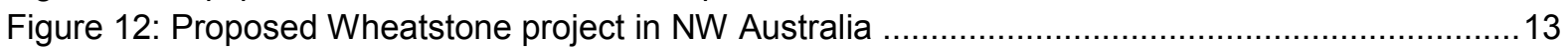

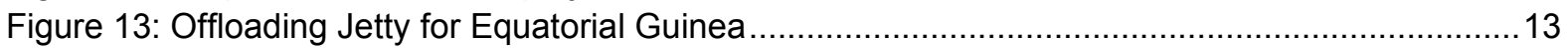

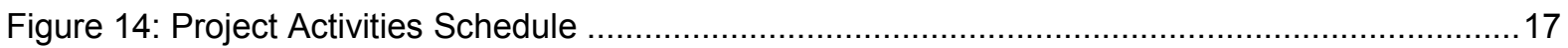

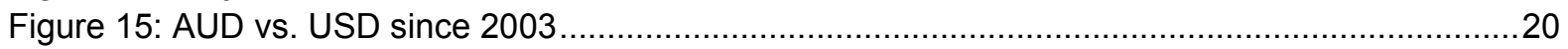

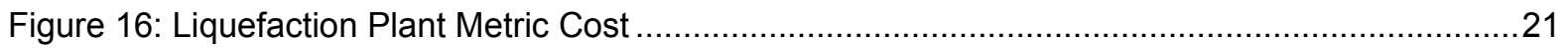

Figure 17: Liquefaction Plant Metric Cost Excluding High Cost Locations ........................................22

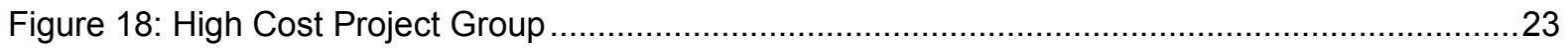

Figure 19: Cost Trends - Additional Train vs. Grass Roots (excluding high cost projects) ...............24

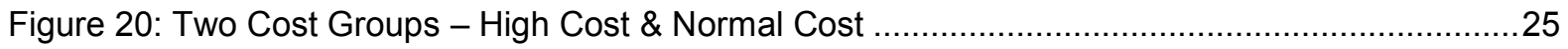

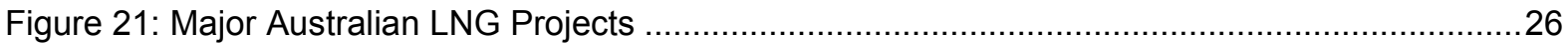

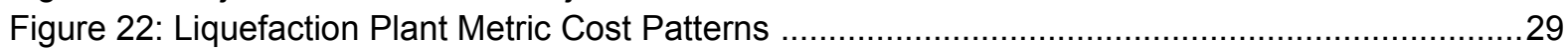

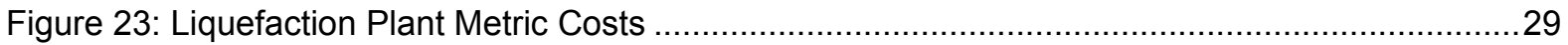




\section{Chapter 1}

\subsection{Context \& Reason for Paper}

The decade of the 2000s saw the emergence of certain developing nations, one subset often referred to as the "BRICS"1, in terms of rapid economic growth. A very visible consequence of this was the rise in oil, gas and other commodity prices as these economies' import requirements disturbed the equilibria of global markets.

A less appreciated consequence of this growth acceleration, especially on the part of China and India, was the increase in the unit cost of upstream capex, power sector projects and wind turbine projects. Indices tracking these three measures showed a near real-terms doubling between 2003 and 2009 , as shown in Figure 1.

\section{Figure 1: Cost Indices 2000 to 2012}

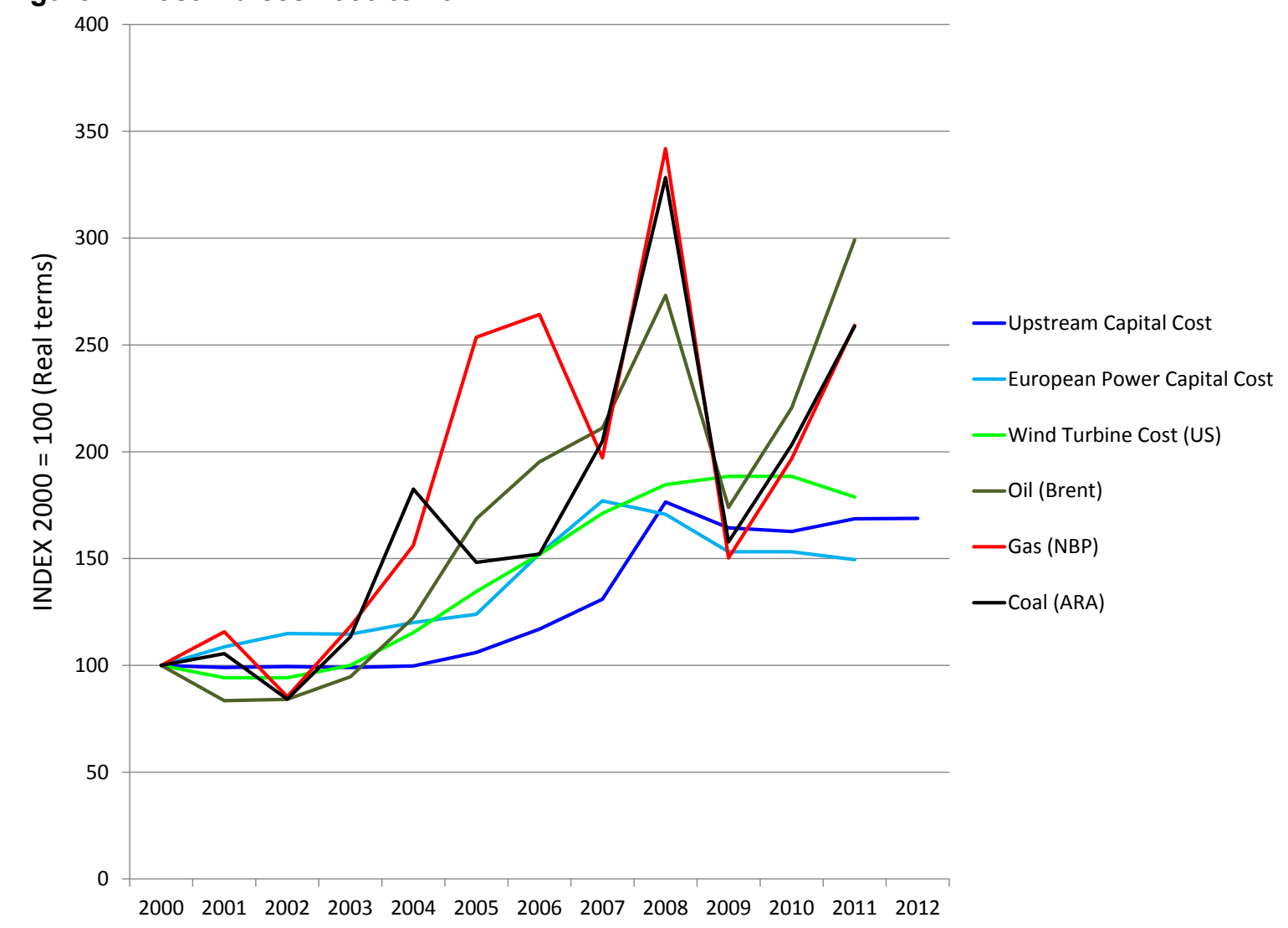

Sources: BP Statistical Review of World Energy(2013), IHS CERA

http://www.ihs.com/info/cera/ihsindexes/index.aspx, IRENA

http://www.irena.org/DocumentDownloads/Publications/RE Technologies Cost Analysis-WIND POWER.pdf

Liquefaction unit costs appeared, on the face of it, to treble or even quadruple in this time period. Figure $2^{2}$ generated from data produced by Wood Mackenzie based on its estimate of the capital 
costs of 36 liquefaction projects between 1965 and the present shows a quadrupling of costs from the low point in the year 2000 to 2013 i.e. from $\$ 300 /$ tpa to $\$ 1,200 /$ tpa.

Figure 2: Liquefaction Capex Trends in US\$

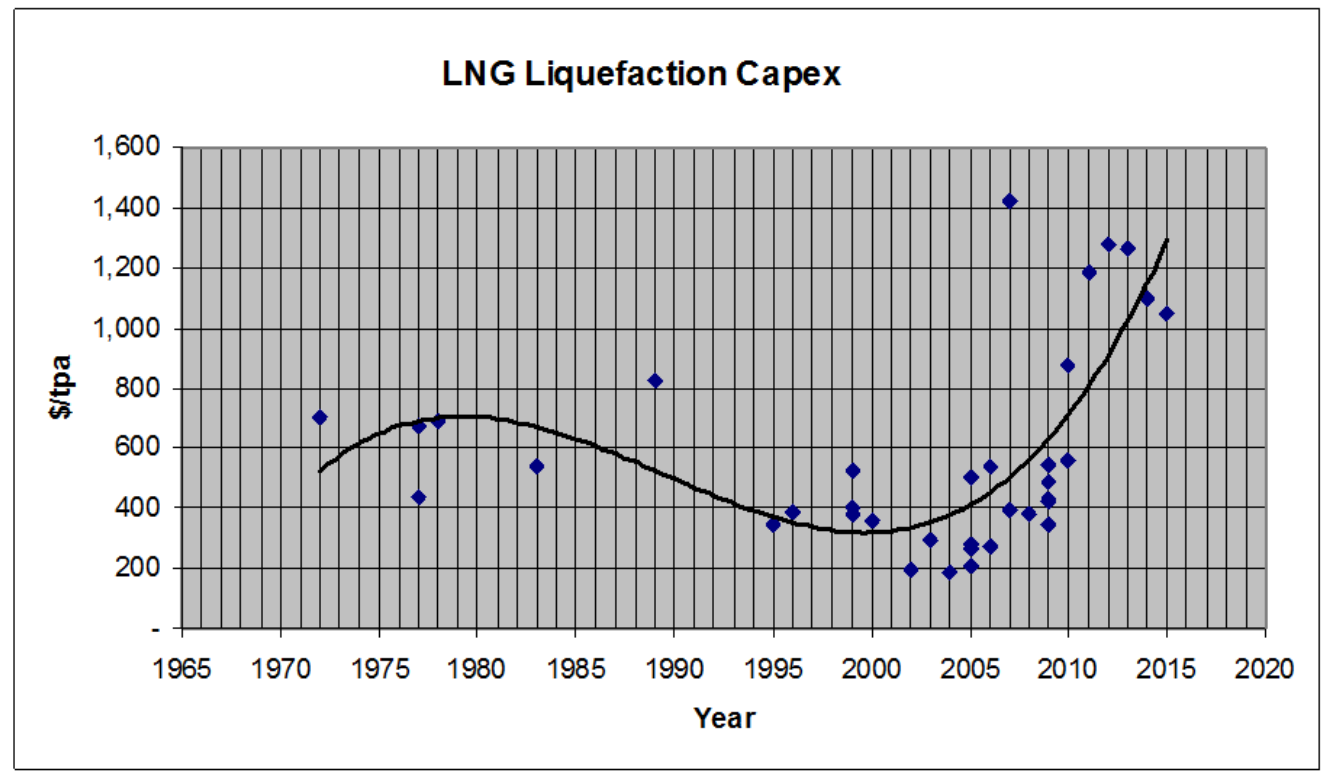

Data from Wood Mackenzie (used by permission)

Source: Wood Mackenzie

Why liquefaction plant costs should rise much faster than other EPC sector costs, as shown by the IHS CERA Upstream Capital Costs Index (UCCl) index in Figure 3, has not been satisfactorily explained. This index shows just over a doubling of the costs in the same 2003-2013 period. Based on this comparison liquefaction plant costs have increased at twice the rate of other upstream oil and gas facilities during that period.

Figure 3: Upstream Capital Cost Index (UCCI)

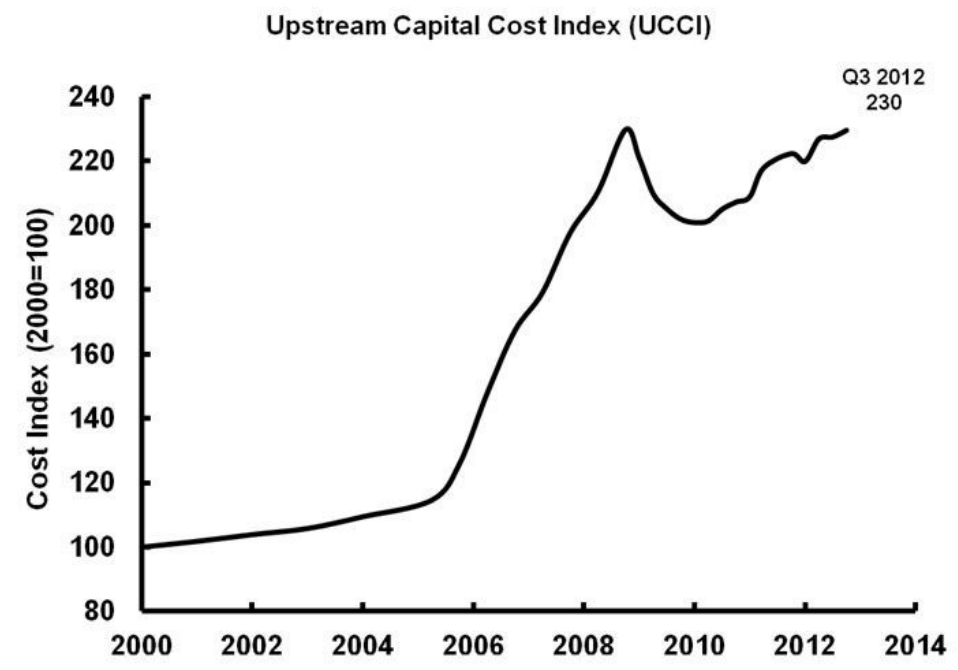

Source: IHS CERA Upstream Capital Costs Index (UCCI) http://www.ihs.com/info/cera/ihsindexes/index.aspx 
This paper provides a comparative analysis of liquefaction plant projects sanctioned during the period 2000 to 2012 and attempts, where possible, to normalise the data (an 'apples and apples' adjustment) and isolate the primary drivers of exceptional cost base inflation responsible for the observed trends. The paper also addresses potential future scenarios which could result in a deflation of liquefaction plant costs such that they are more aligned to the trend of other EPC cost indices. In this paper liquefaction plant refers to the complete facility to treat and liquefy the gas, store the produced LNG and export it via a jetty together with the required utility systems and other necessary infrastructure. A liquefaction train refers purely to the liquefaction process train only.

Research Questions

How has LNG cost inflation trended relative to other EPC sector indices in the 2000 to 2012 period?

Of this LNG cost escalation, what can be attributed to steel and other commodity input costs?

Is there a component attributable to inherently 'more difficult projects' and also the preponderance of Australian projects, given that country's uniquely high cost operating base?

Is there a residual driver which is attributable to higher margins earned by the relatively few specialist liquefaction contractors?

Through time might we expect such a margin to be eroded through competition, or will continued demand for liquefaction facilities and the barriers to entry (technology patents/licences or lack of skilled human resources) maintain the current level of high unit costs?

Are there scenarios which could bring about a significant deflation of the liquefaction cost base? 


\section{Chapter 2}

\subsection{Liquefaction Plant Capacity}

World scale LNG production started in Algeria in 1964 when LNG was first exported to France and the UK. The Kenai plant in Alaska commenced operation in 1969 and its output was exported to Japan. Today there are more than 40 liquefaction plants (export plants) worldwide producing nearly 300 million tonnes per annum (mtpa) and these are listed in Appendix 1. Production is expected to double to around 600 mtpa by 2025.

Figure 4 shows the growth in LNG production worldwide since 1964 and planned production for the next 20 years.

Figure 4: LNG Production by Year - Actual to 2012

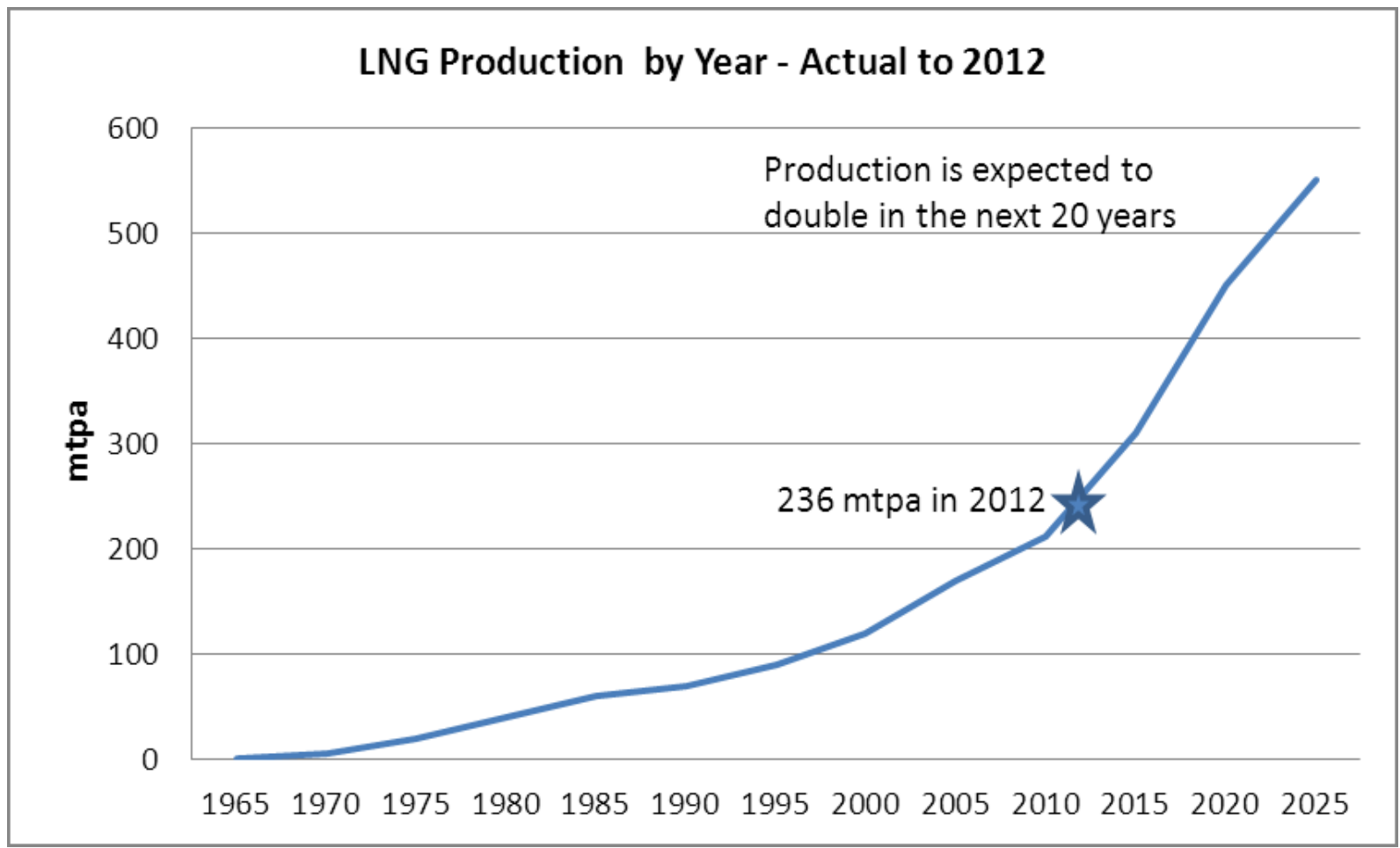

Source: IGU World LNG Report - 2011, GIIGNL LNG Industry Report 2012,

Figure 5 shows the increase in the capacity of individual liquefaction trains used in various projects through time. The largest trains constructed to date have a capacity of $7.8 \mathrm{mtpa}$ and are located in Qatar. Current and planned plants are more typically in the range of 4-5 mtpa per train. 
Figure 5: Liquefaction Train Size Growth

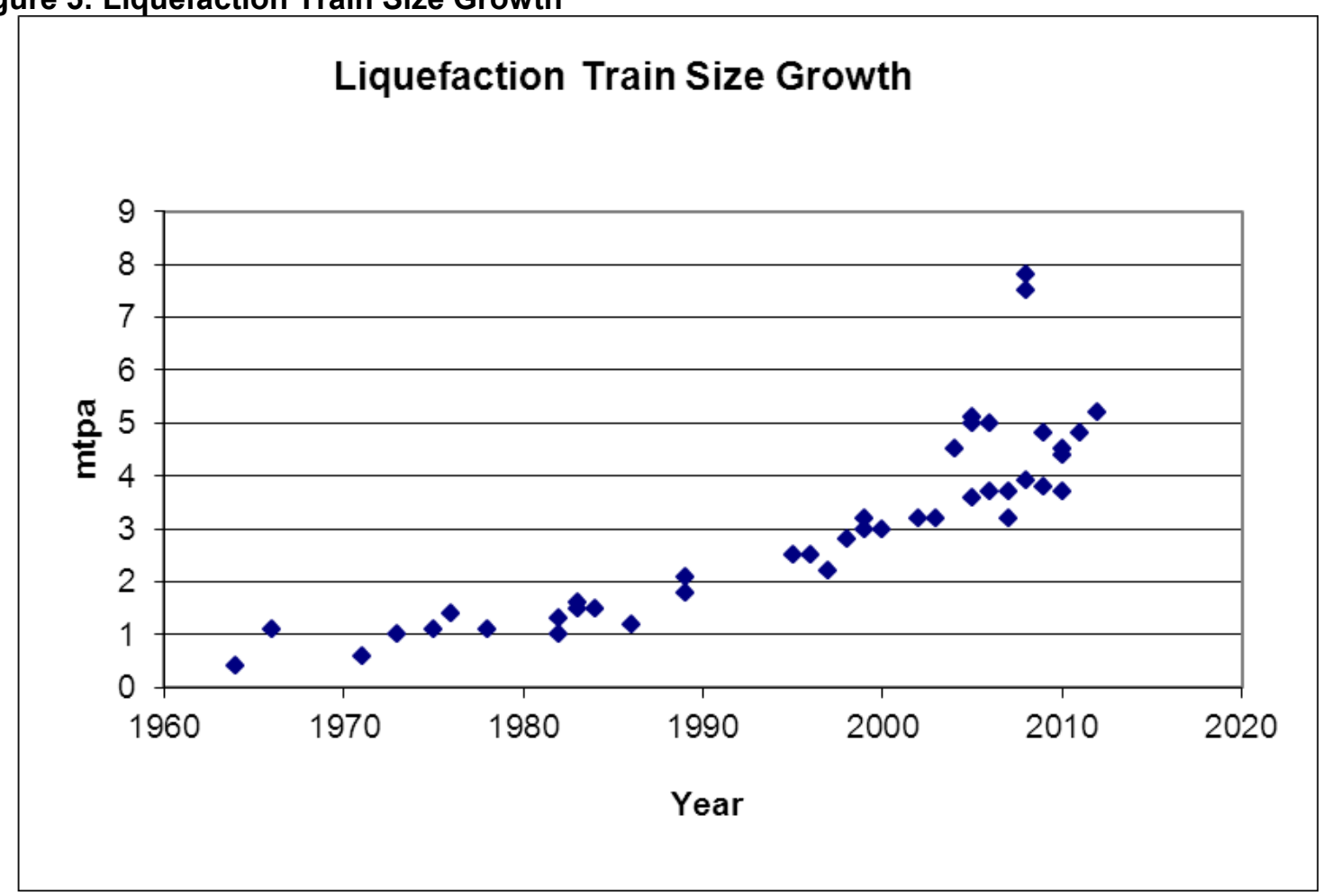

Source: Data from published LNG plant data in various industry reports and summarised in the list of LNG plants contained in Appendix 1. 


\section{Chapter 3}

\subsection{Liquefaction Plant Metric Costs ${ }^{3}$}

For cost comparison purposes the cost of liquefaction plants is normally expressed as a metric cost of US\$/tonne per annum (\$/tpa) and calculated as:

\section{Metric Cost $\$ /$ tpa $=$ Cost of the plant in millions of US\$/capacity in million tonnes per annum}

The curve in Figure 6 shows the trend of the metric cost by year, based on data from Wood Mackenzie $^{4}$. The year stated is the start-up date. Liquefaction plants typically take 10 years to develop from concept to production, including 4 years for site construction.

The curve shows that the metric cost for the early plants in the period $1970-1990$ averaged $\$ 600 /$ tpa, dropping to an average of $\$ 400 /$ tpa in the period $1990-2008$ as the plants increased in size, reflecting an economy of scale and learning by the industry.

However, from 2008 the metric cost increased dramatically to an average of $\$ 1200 /$ tpa for projects executed in the period 2011-2015. Over the period 2000 to 2012 this represents a $300 \%$ increase compared with an average of $100 \%$ for the upstream oil and gas industry generally.

\section{Figure 6: Historical Trend in 2008 Dollars}

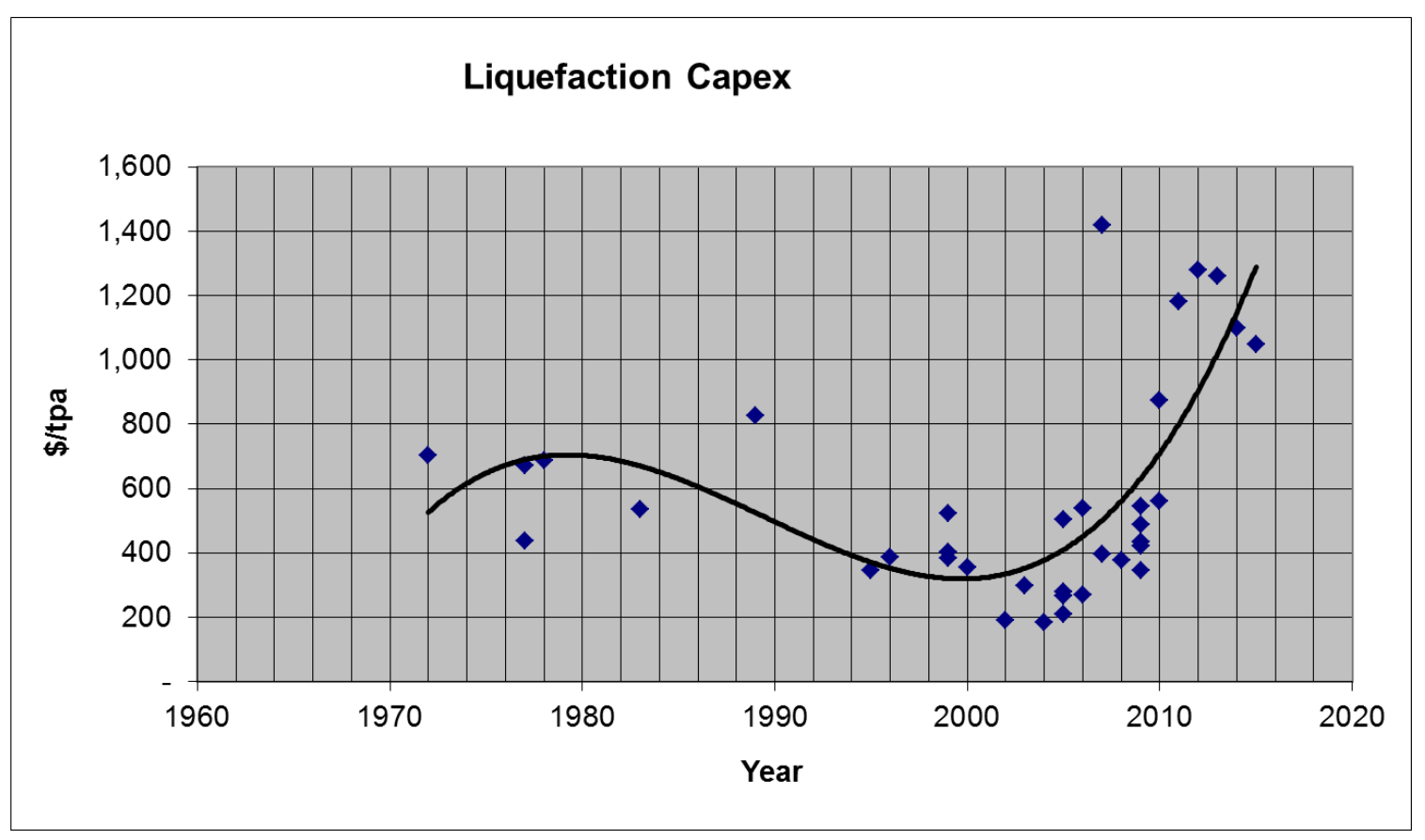

Source: Wood Mackenzie

\footnotetext{
${ }^{3}$ Please note that $1 \mathrm{mtpa}$ is broadly equivalent to $1.37 \mathrm{bcma}$ or $0.133 \mathrm{bcf} /$ day of natural gas in the gaseous phase although this varies with the exact composition of LNG.

${ }^{4} \mathrm{BP}(2012)$
} 


\subsection{Methodology}

The following approach was used to prepare this paper:

For the liquefaction plants built since 1964 the following data was collected - plant costs, startup date, facility scope, location and capacity (tonnes/annum). These were gathered from published information and reports, industry contacts and other industry sources, including the author's own data base. The physical and process scope of the plant is a critical cost driver as projects vary enormously in this respect. Whilst they all contain a basic liquefaction unit (liquefaction train), the infrastructure - marine facilities including jetty, possible dredging and breakwater, LNG \& NGL storage tanks, power station, construction camps and operations township, including possible airstrip - does vary significantly.

The costs were broken down into the key components where possible to ensure a like for like comparison. Obtaining this level of cost detail was very difficult and not always possible given the commercial confidentiality of this information.

A base liquefaction plant cost break down was established using industry published data to quantify the key cost components, namely the engineering, procurement, construction and the owner's costs.

The plant metric cost was calculated for each project and compared with data from other sources. This metric cost is used universally within the LNG industry to compare liquefaction plant costs.

The metric cost for each plant was plotted against the start-up date to determine the metric cost trend by year.

The trends were analysed using the two major cost drivers;

Scope - a new complete facility (often referred to as a 'grass roots' development) requiring the full infrastructure vs. a liquefaction train only which uses most of the existing infrastructure (often referred to as 'brownfield')

Location - which drives transportation and construction costs. For example, remote locations require extensive new infrastructure for transporting equipment and personnel and accommodating construction staff compared with established industrial areas that frequently have the full infrastructure in place.

The data and the trends were analysed to predict future LNG plant costs and identify areas where future plant costs could be reduced.

The analysis and findings were reviewed by four senior LNG professionals, one from a major lending bank in the LNG industry, one from a major EPC contractor, one from a commercial LNG consultancy and one from a major LNG producer. Their comments were incorporated in this report. 


\section{Chapter 4}

\subsection{LNG Plant Cost Breakdown and Drivers}

\subsection{Cost Breakdown}

Based on data collected by the author from various projects average cost breakdowns were calculated as shown in Figures 7 and 8.

Figure 7 shows costs broken down by plant area. The analysis shows that the liquefaction plant typically represents about $50 \%$ of the total plant cost. This explains why the cost for a repeat liquefaction train may only be $50 \%$ of a completely new facility.

Figure 7: Cost Breakdown by Plant Area

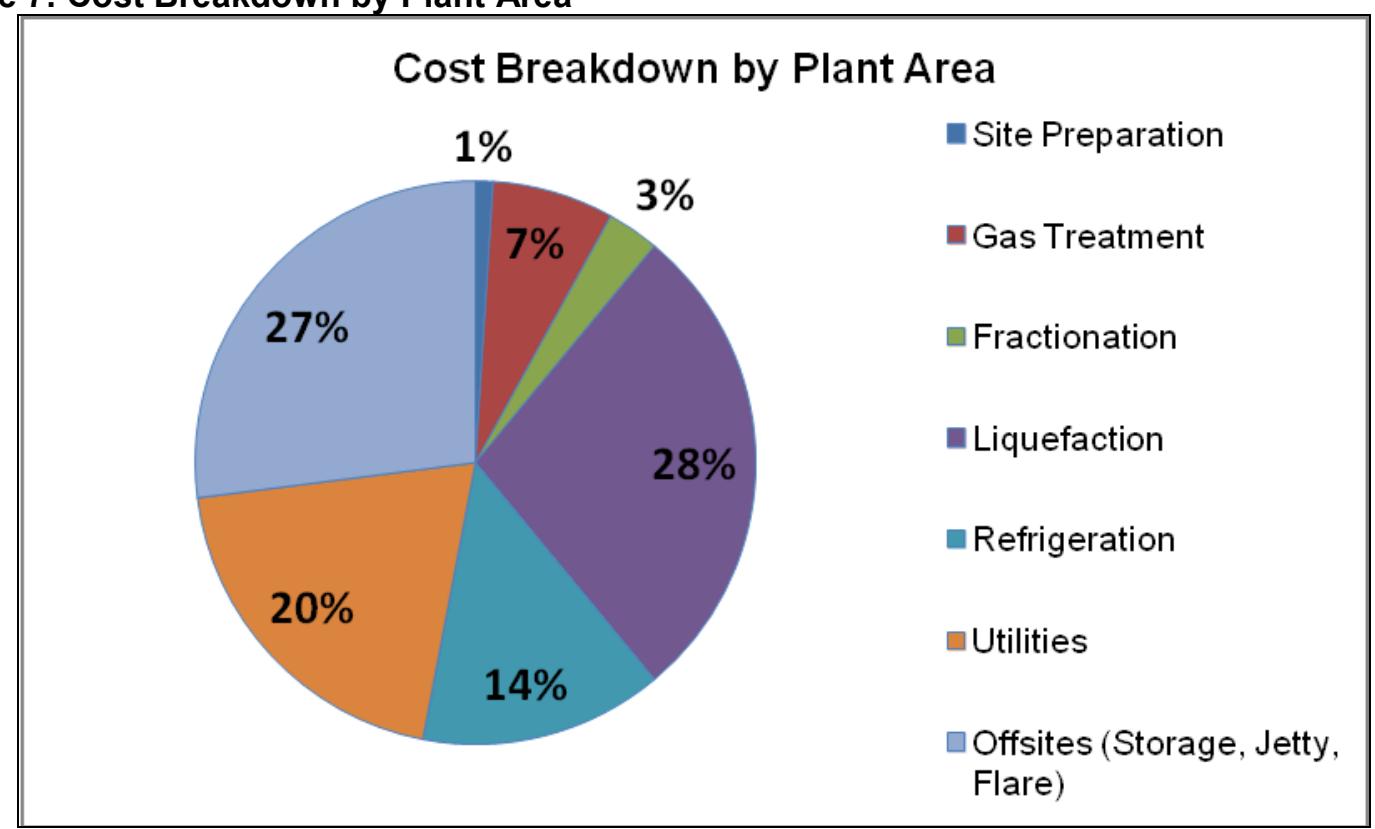

Source: Published Data from Various Projects

Figure 8 depicts cost breakdown by category, showing that the largest single cost item is construction at $35 \%$ historically. Hence projects in areas with high construction costs such as Australia will be far more expensive and construction can account for up to $50-60 \%$ of the project cost. 
Figure 8: Cost by Category

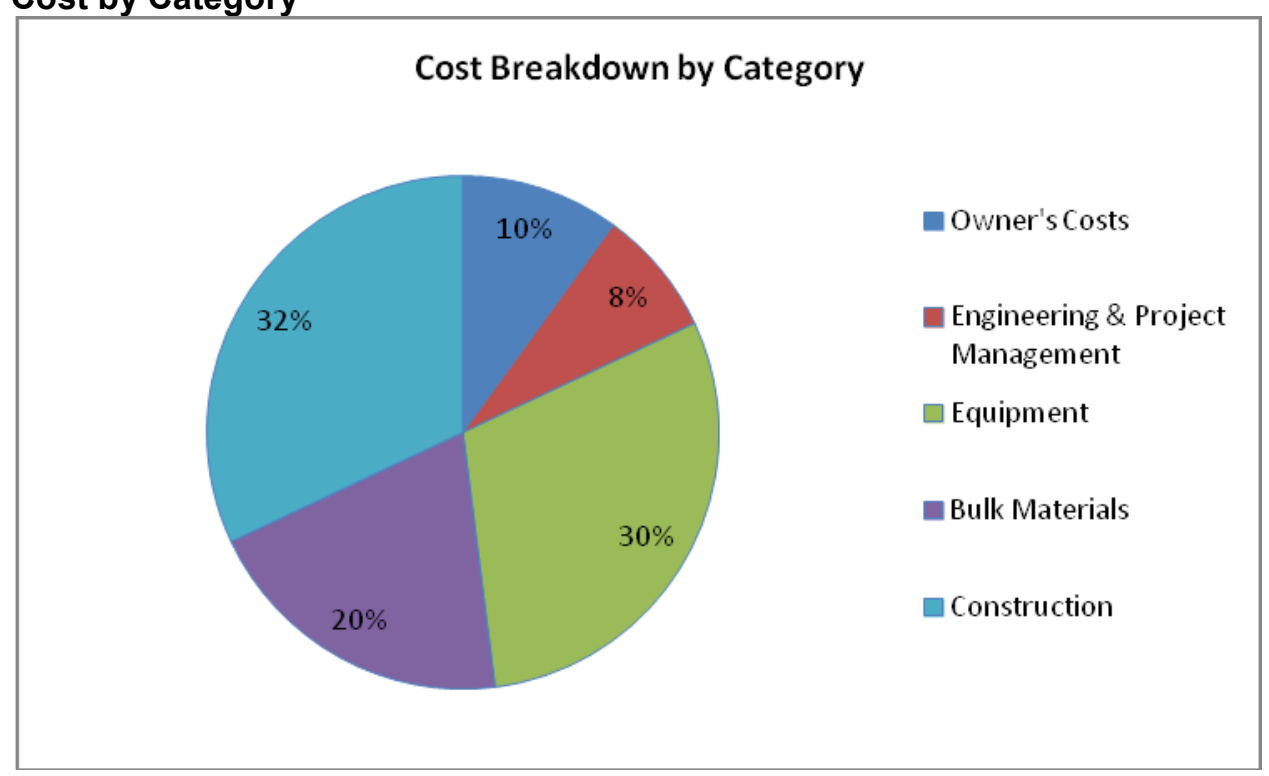

Source: Published Data from Various Projects

\subsection{Cost Drivers}

The principal cost drivers for liquefaction plants are, in order of significance:

\section{Project Scope}

Project Complexity

Location (Infrastructure \& Construction Costs)

Equipment \& Materials

Engineering and Project Management

Contractor Profit \& Risk

Owner's Costs

Contract Strategy

Currency Exchange Risk

\subsection{Project Scope}

As stated earlier, liquefaction plants range from simple liquefaction trains added to an existing plant through to a completely new facility requiring all the necessary infrastructure, including possibly an air strip, construction camp, township, roll-on/roll-off dock, breakwater and dredging. Some projects (Gorgon and Snøhvit) even include carbon capture and storage ${ }^{5}$. These scope changes can double or treble the plant costs for the same capacity and thus increase the metric cost dramatically. Figure 9 illustrates the range of project scopes.

\footnotetext{
${ }^{5}$ In these projects $\mathrm{CO}_{2}$ is a naturally occurring impurity in the gas reservoir and must be removed during gas processing by ethanolamine scrubbing facilities. The $\mathrm{CO}_{2}$ is then compressed and stored underground in suitable strata via purpose drilled injection wells. [There are many other naturally occurring impurities in gas streams which have to be removed. The difference with $\mathrm{CO}_{2}$ is that it is a greenhouse gas which must be controlled.
} 


\section{Figure 9: LNG Plant Scopes}

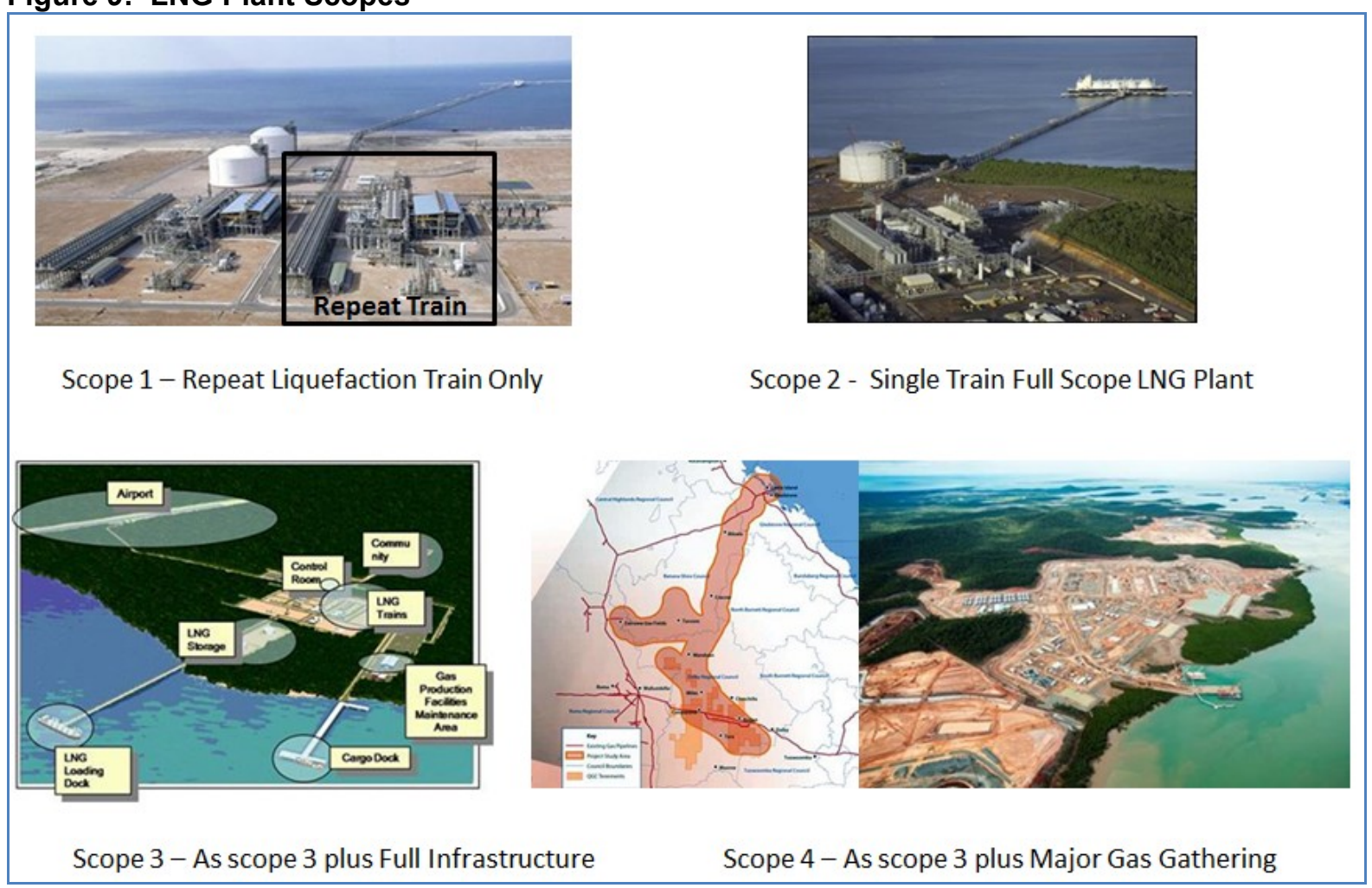

Source: Published Data from Various Projects - refer to hyperlinks below.

Scope 1: http://www.petroleum.gov.eg/en/ProjectsandActivities/StrategicProjects/Pages/ldku.aspx

Scope 2: http://www.conocophillips.com.au/EN/business/OurProjects/Pages/DarwinLNG.aspx

Scope 3: http://www.bp.com/en/global/corporate/about-bp/bp-worldwide/bp-in-indonesia.html

Scope 4: http://www.aplng.com.au/about-project/about-project,

Scope 1 is the simplest comprising only a repeat liquefaction train with minimal gas treatment. This minimises the engineering and procurement as it is essentially just a repeat train e.g. Idku.

Scope 2 is the complete LNG facility including gas processing, liquefaction, storage and export jetty but not requiring extensive infrastructure for construction as it is close to an established town providing accommodation, port facilities and airport e.g. Darwin.

Scope 3 is the same plant scope as Scope 2 but includes the full infrastructure to support the construction and subsequent operation and maintenance of the plant, such as construction camp, new township, port facilities and airport e.g. Tangguh.

Scope 4 is the same plant scope as Scope 2 but includes the major upstream gas gathering infrastructure. In the case of the coal bed methane (CBM) projects in Queensland, this has been stated to be $50-55 \%$ of the total project cost thus doubling the cost of the project when compared with gas delivered to the gate of the liquefaction plant using an existing pipeline e.g. APLNG. 


\subsubsection{Plant Units}

Figure 10 shows the full list of processing units that may be included in a liquefaction plant. However not all plants have all these components.

Figure 10: Full Scope Plant

\section{Full Scope Plant}

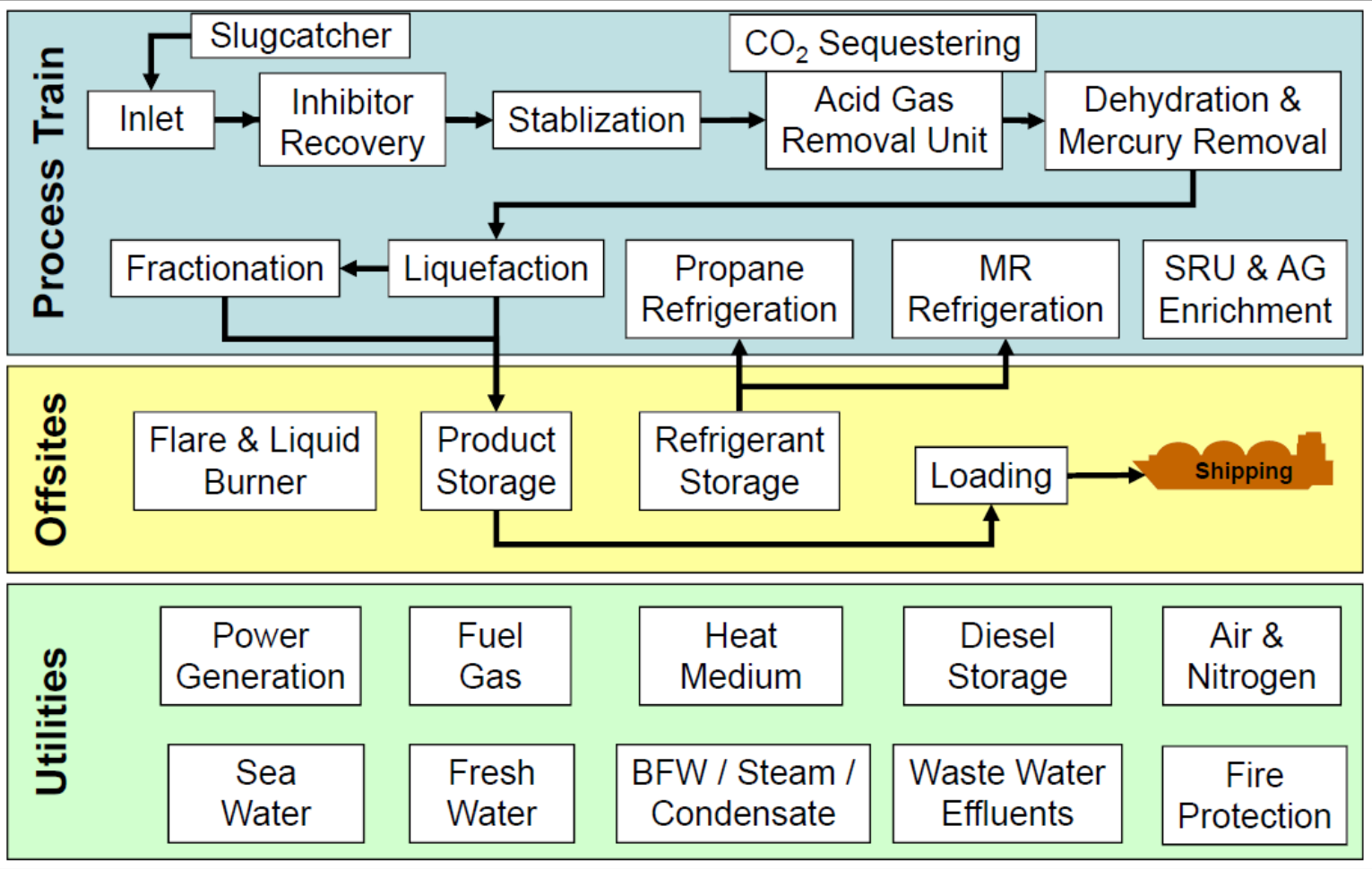

Source: KBR (2007)

As an example, an expansion comprising just a repeat liquefaction train will likely only comprise the process train components. A process train taking lean gas from a sales gas pipeline will not require a slug catcher and fractionation to extract natural gas liquids. Similarly, only very sour gas facilities will require sulphur recovery. If power is available onsite then power generation will not be required.

Figure 11 shows how the number of items of equipment required to build the plant increases with increasing scope. 
Figure 11: Equipment Count Increase vs. Scope

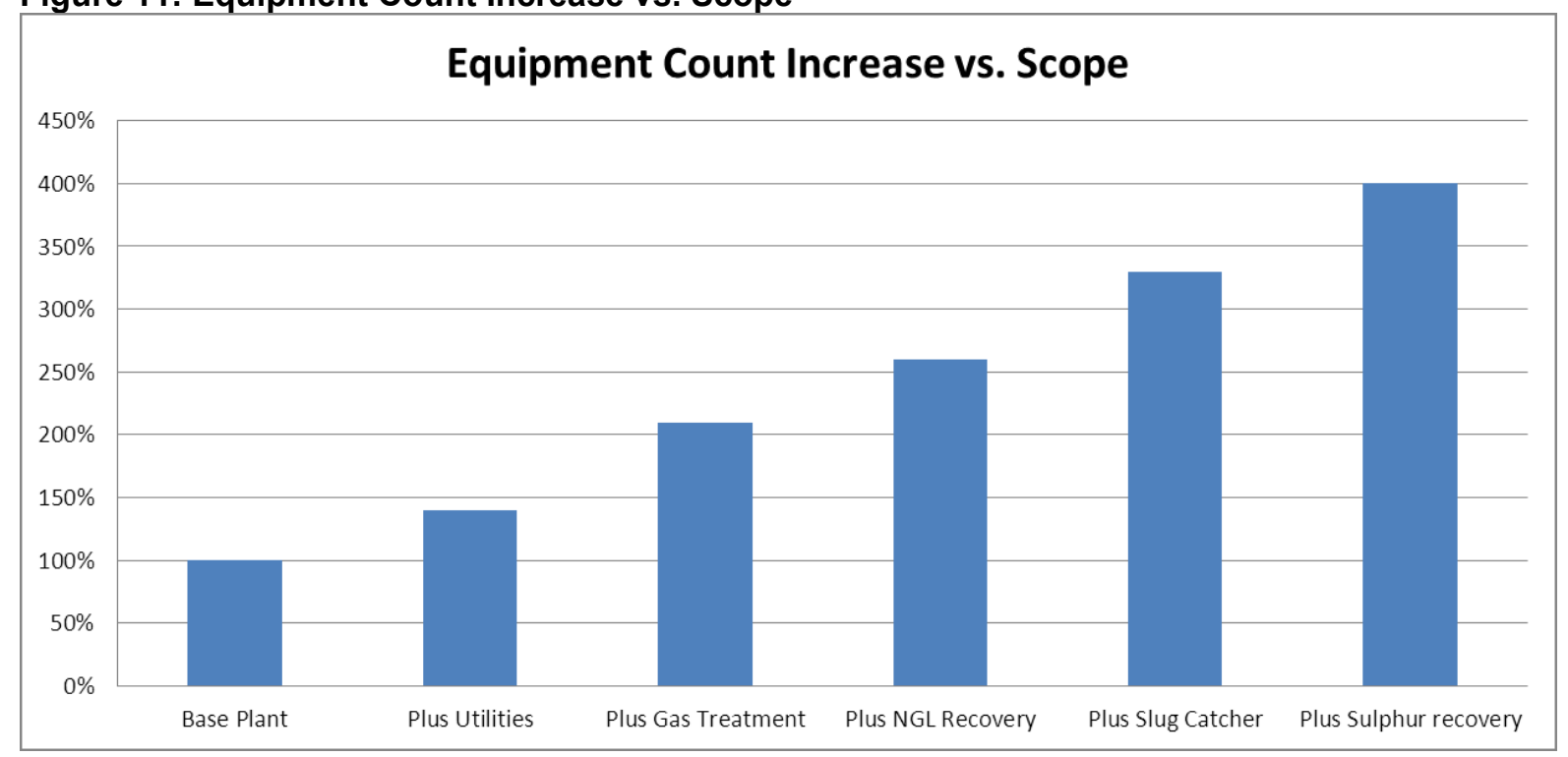

Source: KBR (2007)

\subsection{Marine Facilities}

Marine facilities can be a very significant cost depending on the location. These typically include as a minimum the jetty head and jetty trestle linking to the shore but can also include a breakwater as well as extensive dredging to enable ships with a draft of 12 metres to enter the harbour and moor at the jetty and to turn around so they face outward in the event of having to leave in an emergency. The initial dredging costs are capital costs but ongoing maintenance can also lead to a significant operating cost. One of the projects planned for British Columbia is even considering a tunnel for running the LNG export loading lines. Tunnels are already used on import terminals in the USA and Japan but are a very costly item.

Marine facility costs are becoming so significant on many projects that they are now listed as a separate line cost item at the process plant level rather than at sub-cost element level.

An example is the proposed Wheatstone project in NW Australia shown in Figure 12 where the dredging cost is estimated at $A \$ 1.5$ billion. This includes the dredging of a $17 \mathrm{~km}$ approach channel, a manoeuvring area, the berthing pockets and the tug harbour. The total dredged volume will exceed 26 million $\mathrm{m}^{3}$ of material and the works will be executed under strict environmental conditions. 

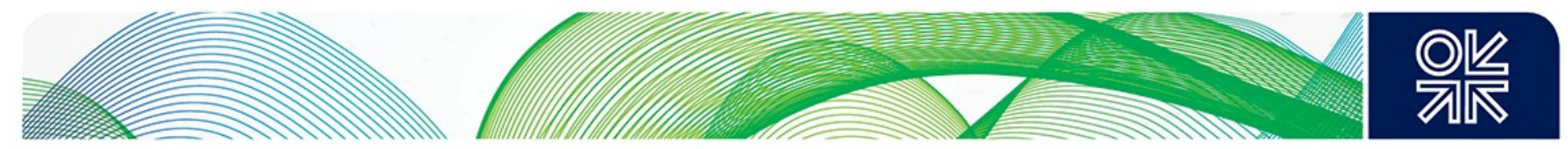

Figure 12: Proposed Wheatstone project in NW Australia

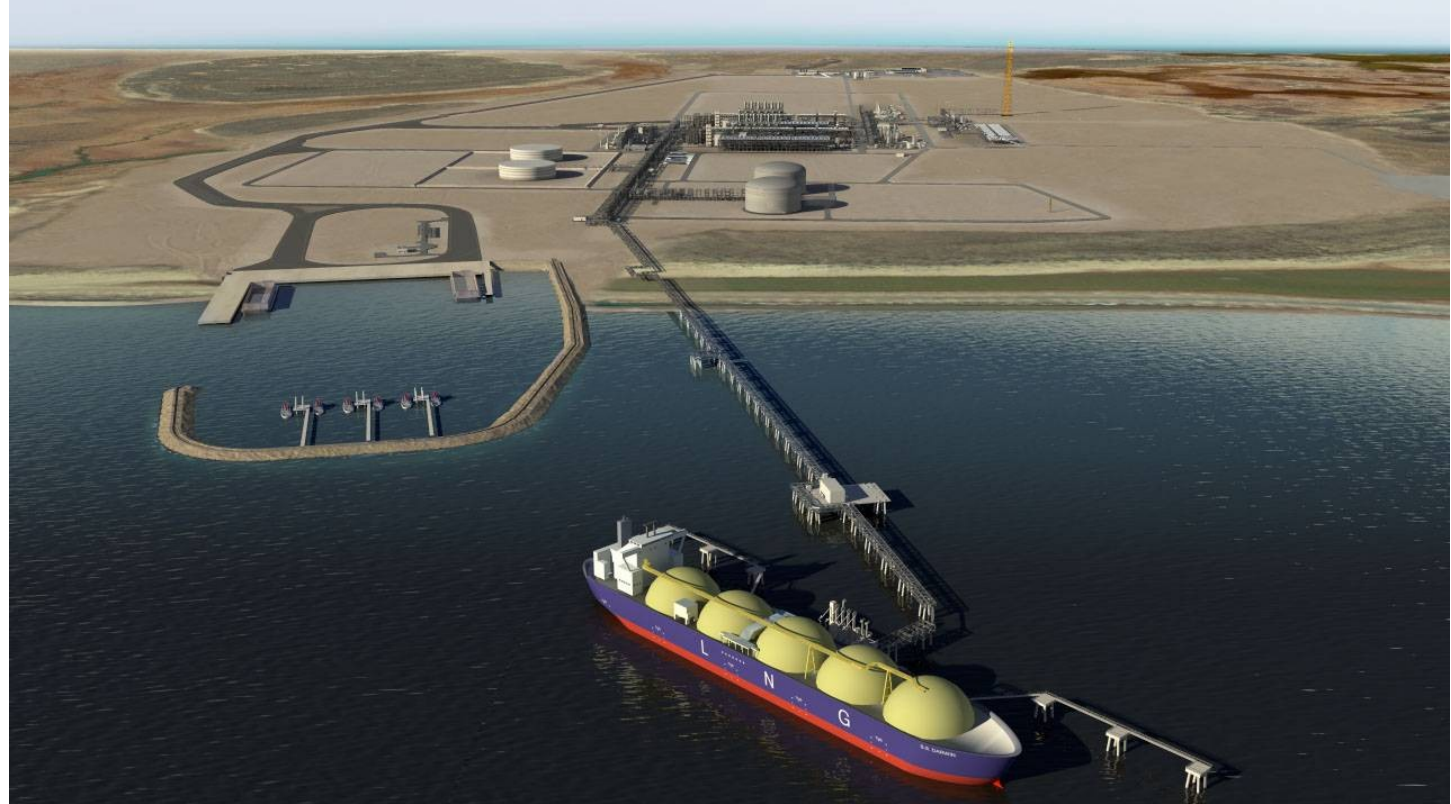

Source: Woodside

Another example is the complex offloading jetty for Equatorial Guinea which uses a suspension bridge as shown in Figure 13.

\section{Figure 13: Offloading Jetty for Equatorial Guinea}

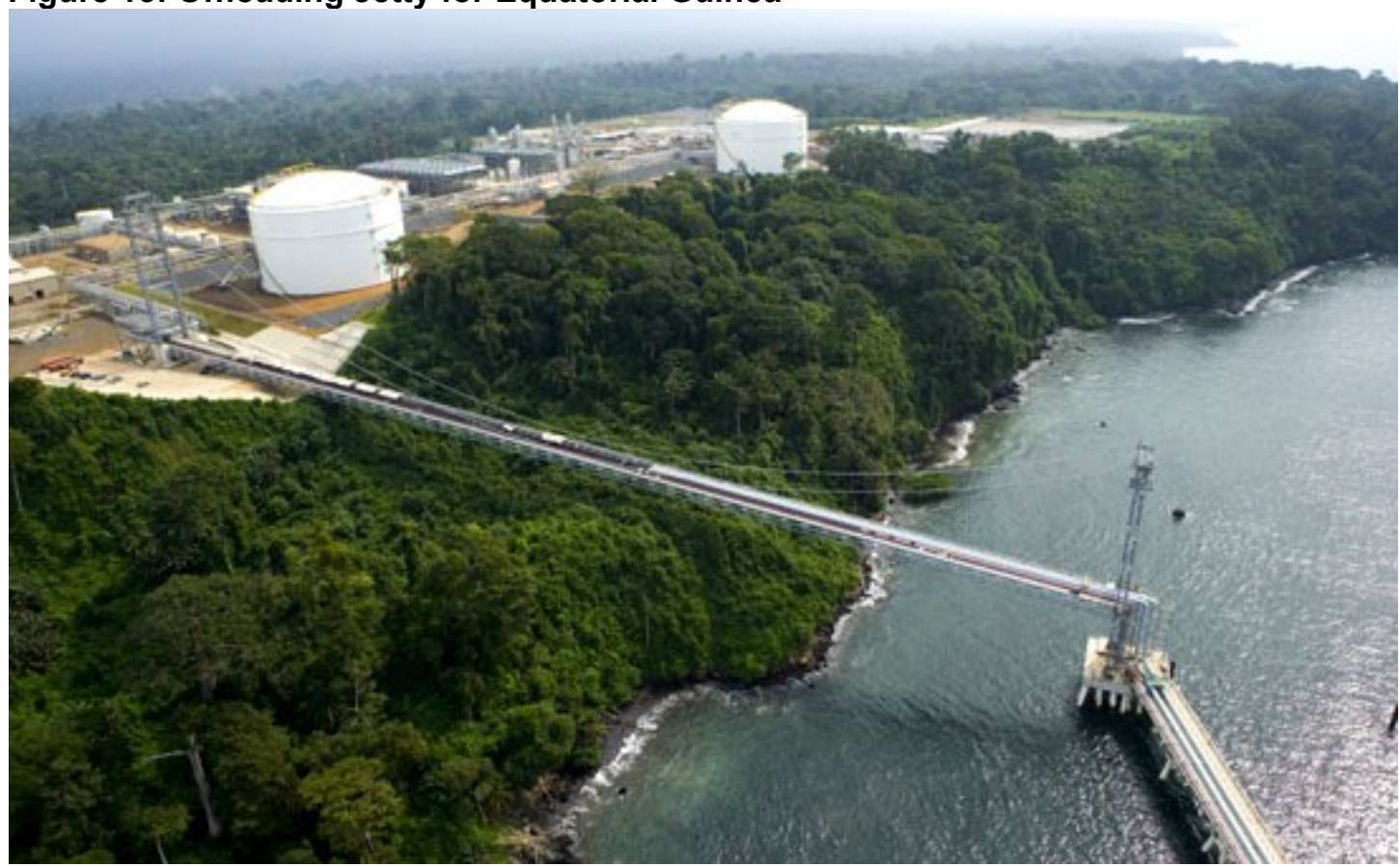

Source: Equatorial Guinea LNG Holdings Limited ( EG LNG) 


\subsection{Project Complexity}

Projects can vary from relatively straight forward locations with a highly structured in-country LNG business and well established industrialised areas, for example Qatar and the Gulf of Mexico, through less straight forward locations in countries which already have a highly established LNG business but are using very remote locations with no infrastructure, for example Gorgon on Barrow Island, to very difficult countries which are completely new to the LNG business and using remote locations with no infrastructure, for example Mozambique and Tanzania.

These differences increase the level of complexity of executing the project as the challenges become more difficult and therefore significantly increase the cost of managing the project. In particular, the cost and time of undertaking activities prior to making the investment decision will be much higher.

With regard to the countries new to LNG, for example Angola recently and in the future Mozambique and Tanzania, they will not have national standards for LNG plants and there will be an extensive period of familiarisation and local training before all the local stakeholders know their role and are able to approve the project ${ }^{6}$.

Another area of complexity is the use of multiple front end engineering contracts (FEEDs) and often referred to as design competitions to select the EPC contractor. In these situations, 2 or 3 EPC contractors are awarded the FEED phase and, based on a functional specification, are requested to prepare their EPC proposal based on their FEED. These multiple FEED teams require multiple client teams to interface with the different contractors to ensure all the proposals meet the client's requirements. The use of a single FEED contractor to provide the basis for competitive EPC bids is far less complex and the use of a preferred contractor from the outset for the whole project is even simpler and reduces the client pre-sanction costs considerably as well as shortening the project schedule.

Other complexity issues include environmental and permitting issues and multiple owners with different specifications and contracting strategies.

\subsection{Construction}

Construction costs are the major single cost and typically represent $30 \%$ of the total project cost as shown in figure 8. For Australian projects this can increase to $50-60 \%$ as discussed later.

A new build (grass roots) liquefaction plant typically requires a construction team of 6-8,000 people for a period of 4 years, representing 30 million site construction manhours ${ }^{7}$. Labour rates and productivity has a major impact on this cost. Marine facilities, as mentioned earlier, including long jetties, large breakwaters and extensive dredging, can increase the costs significantly.

The cost of construction is primarily driven by plant location and is a combination of construction manhours, labour costs and productivity.

As stated above, the historic figure of $30 \%$ of total project cost was based on pre-Australian projects. Current Australian project construction costs are typically 2-3 times higher than for other locations and

\footnotetext{
${ }_{7}^{6}$ For an in-depth review of the technical and political challenges facing East Africa Gas see Ledesma 2013.

7 Information obtained through discussion with major EPC contractors based on past projects
} 
this has increased the construction component to a staggering $50-60 \%$ of the project $\operatorname{cost}^{8}$. This alone has put a question mark on future land based LNG projects in Australia and floating liquefaction is now being considered as an alternative and Shell has selected FLNG for Prelude and Woodside has now moved to a FLNG concept for Browse ${ }^{9}$.

\subsubsection{Australian Costs}

As Australian costs are so high and significant to this paper it is worth mentioning the following items taken from recent reports:

Australia has become such a high-cost and low-productivity nation that resources projects are now $40 \%$ more expensive to deliver than in the US, jeopardising an investment boom that is crucial to propping up the national economy ${ }^{10}$.

Australian oil and gas workers earn $\$ 163,600$ /year on average, $35 \%$ more than oil and gas employees in the U.S. and almost double the global average, according to a survey this year by a recruiting company. This compares with $\$ 93,400$ in the U.K $K^{11}$.

The budget last year for the Gorgon project jumped by $21 \%$ to $A \$ 52$ billion because of higher labour expenses and gains in the Australian dollar. Similarly, the Queensland Curtis LNG venture budget rose $36 \%$ to $A \$ 20.4$ billion, Pluto a $26 \%$ increase to $A \$ 15$ billion and Ichthys a $30 \%$ increase to $\mathrm{A} \$ 44$ billion $^{12}$.

"Australia is a particular concern on cost inflation," Shell told analysts in November in New York. "Welders can apparently earn $\$ 250,000 /$ year." 13

Landmark research to be released today finds that, compared with the US, airports are $90 \%$ more expensive to deliver, hospitals $62 \%$, shopping centres $43 \%$ and schools $26 \%{ }^{14}$.

\subsection{Equipment \& Materials}

Equipment and bulk material costs typically represent $30 \%$ and $20 \%$ of a liquefaction project respectively. The main equipment costs are the cryogenic heat exchangers, refrigeration compressors and drivers, power plant and LNG storage tanks. As a general observation it can be said that in these relatively specialised areas there is limited competition. The refrigeration compressors and their gas turbine driver are supplied exclusively by General Electric, despite major efforts by Dresser, Siemens and Rolls-Royce to break into this market and increase competition.

The typical suppliers of the main equipment items are:

Cryogenic Heat Exchangers/Cold Boxes - Chart, Air Products and Linde

Refrigeration Compressors - General Electric (GE)/Nuovo Pignone exclusively

\footnotetext{
${ }^{8}$ Ditto as above

${ }^{9}$ Examples are Browse http://www.gastechnews.com/Ing/browse-decision-highlights-cost-benefits-of-flng/, Scarborough http://www.platts.com/latest-news/natural-gas/sydney/exxonmobil-welcomes-australian-approval-for-scarborough-27630144 ${ }^{10} \mathrm{http}: / /$ www.theaustralian.com.au/national-affairs/local-project-costs-40pc-above-the-us/story-fn59niix-1226386836012\#mmpremium

http://online.wsj.com/article/BT-CO-20130207-718721.html

http://www.smh.com.au/business/mining-and-resources/floating-Ing-as-costs-blow-out-20130426-2iihr.html http://www.bloomberg.com/news/2013-04-25/highest-paid-workers-driving-shell-gas-terminal-offshore.html http://www.theaustralian.com.au/national-affairs/local-project-costs-40pc-above-the-us/story-fn59niix-1226386836012\#mmpremium
} 
LNG Storage Tanks - CB\&I, Tractebel, Samsung C\&T, Whessoe, Bechtel/Thiess TKK/BG\&E (Darwin), Techint/Sener/Entrepose/Vinci

It should be noted that most of the other equipment is standard oil and gas equipment and should not be more expensive for LNG projects. The exception to this is an extensive use of stainless steel for equipment and materials including piping that handles LNG at cryogenic conditions (typically $-160^{\circ} \mathrm{C}$ ). Stainless steel is considerably more expensive than carbon steel.

An interesting characteristic of the recent plants in Australia is that the major suppliers have been asked to modularize their equipment ${ }^{15}$ to minimize construction work at the site due to the high costs and personnel restrictions (i.e. labour union-backed laws which limit the import of skilled trades for construction projects ${ }^{16}$. Feedback indicates that while companies such as GE are excellent at providing world class gas turbines and compressors, modularization is not their area of expertise. This has led to high costs and extended schedules for work that could be performed more effectively by a specialist fabricator who is able to design and fabricate modules more cheaply and quickly. This area is discussed further in suggestions for cost reduction.

\subsection{Engineering \& Project Management}

Engineering and Project Management (EPM) typically represents $8 \%$ of the project cost (capex) and covers the detailed engineering and project and construction management costs of the EPC contractor.

There are six main EPC contractors providing world scale LNG plants - Bechtel, KBR, Foster Wheeler, Technip, CB\&I, JGC and Chiyoda.

All are located in the major oil and gas design centres of the world - London, Paris, Houston and Tokyo. They all have similar productivity and cost base (labour costs) and all use high value design centres to reduce costs for detailed design and drafting. These are typically located in India, Mexico and the Philippines.

It should be noted that these contractors are all active in other oil and gas facilities such as upstream, refineries and petrochemicals and use the same professional human resource 'pool' other than for some specialist LNG engineers. As such the cost of the E\&PM services should rise in line with normal oil and gas escalation and not carry an LNG premium.

\subsection{Owner's Costs}

These costs typically include the costs of the owner's project team and support services to oversee all aspects of the project both technically and commercially from project commencement to handover to the operations department. They include the cost of all specialist contractors and consultants used during the period prior to Final Investment Decision (FID) for activities such as feasibility studies, conceptual design, front end engineering design (FEED), environmental impact assessment studies, drawing up commercial contracts for the purchase of the feed gas and the sale of LNG, working with

\footnotetext{
${ }^{15}$ This refers to the project execution approach where process plant is constructed in units or 'modules' at a remote (usually highly efficient/moderate cost location) and assembled and connected together in a relatively straightforward manner at the project site.

http://pmbook.ce.cmu.edu/04 labor, material, and equipment utilization.html
} 

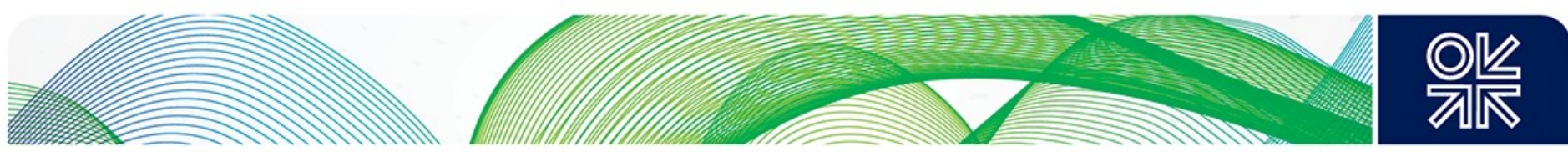

the project financiers (banks) and the government organisations and other approval bodies for permitting.

These activities and their sequence are described in Figure 14.

For major liquefaction projects the likely overall schedule is 10 years from initial planning stage to plant start-up. Construction normally takes 4 years.

Typical timescales on figure 14 for a liquefaction project are as follows:

Evaluation -

Feasibility -

Appraisal \& Optimisation -

Development -
1 year

2 years

2 years

5 years (FEED \& bidding 2 years, EPC 4 years)

Figure 14: Project Activities Schedule

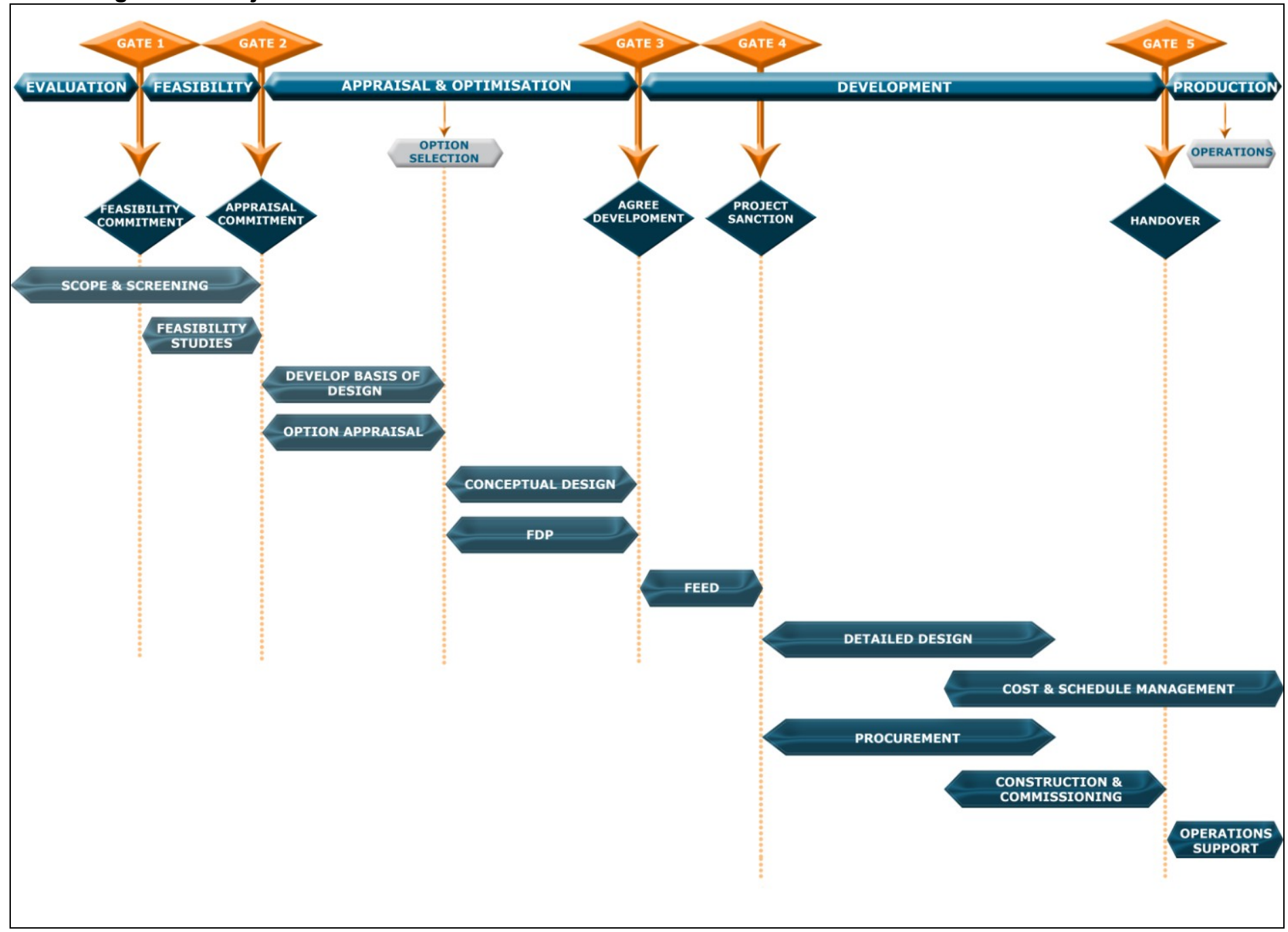

Source: TK Uhde Energy \& Power

http://www.thyssenkrupp-uhde-energyandpower.com/en/services/project-management.html 
Owner's costs typically represent $10 \%$ of the project cost but vary greatly depending on the owner's involvement, driven mainly by the complexity of the project. Prior to this period of high cost projects, owners typically had only small teams of around 40 but recent complex projects have increased this number to 200 , i.e. by a factor of 5 or even more. This increase has been due to the higher complexity of the projects and, in many cases, due to an increase in the number of partners.

As stated earlier, there has also been a tendency to award multiple FEED contracts as 'design competitions' to 2 or 3 EPC contractors and this has increased owner's costs and extended the schedules when compared with the sole sourced route previously used. Managing three contractors undertaking a design competition typically means three client teams located in the contractors' offices, typically in different parts of the world, leading to a significant increase in costs and a high demand on the industry's resources. These personnel could be managing and working on other projects.

In addition, the move from lump sum EPC contracts towards EPCM contracts (construction management only) with construction costs awarded on a reimbursable basis has led to much larger client teams in order to manage this reimbursable component.

It is not unusual now for the owner to spend in excess of $\$ 1$ billion on a project costing $\$ 15-20$ billion prior to project sanction (FID), representing $5-6 \%$ of the investment cost.

\subsection{Contract Strategy}

This can vary from the award of a single sole sourced negotiated EPC contract through to the bidding and award of separate contracts for marine, tanks, plant and infrastructure facilities. As mentioned earlier, multiple FEED (front end design) contracts have been awarded as design competitions again adding considerable project cost and drawing heavily on resources.

Several approaches to the award of the subsequent EPC contract or contracts are used by the different energy companies. These include, in order of increasing cost:

The simplest and lowest cost of award method of developing a high level Basis of Design and the award to an EPC contractor on a sole sourced basis.

The traditional and mid cost method of awarding single conceptual design and FEED contracts to define the scope of the project as the basis for bidding the EPC contract. This is followed by seeking competitive bids from typically 3 different EPC contractors, evaluating those bids, negotiating the contract and award to the selected contractor.

The relatively new high cost 'functional specification' method of developing a high level Basis of Design through a feasibility study which then forms the basis of a FEED or design competition awarded to 2 or 3 EPC contractors. The results of these competitions are evaluated and the EPC contract is awarded to the successful contractor.

Due to the high value of these contracts, consortia are often formed by the EPC contractors to spread the risk and utilise specific contractor strengths such as in-country knowledge. This increases the complexity and management costs of the project.

With regard to the main liquefaction process, most energy companies pre-select this as part of the basis of design. In most cases it is based on their previous experience and operational knowledge thus allowing trained teams to be easily relocated to new projects. 

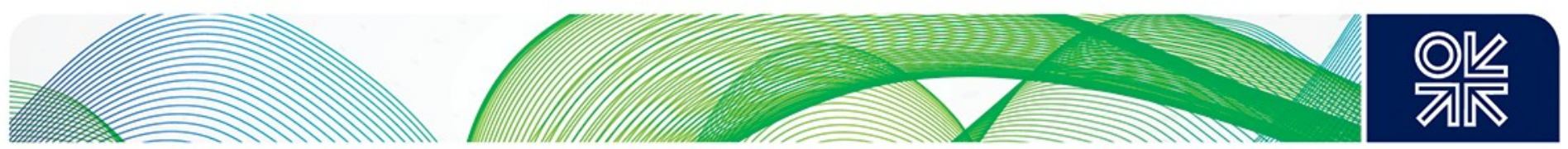

Some interesting comments that have been made during the research for this paper are:

Where there are multiple liquefaction projects on adjacent sites, for example Curtis Island, Queensland and now Mozambique, costs could be significantly reduced by sharing the common infrastructure for the overall facility as opposed to completely independent facilities. This could include the utilities, jetty and marine facilities.

FEED packages tend to focus on the liquefaction plant rather than inlet gas treatment which is more liable to change following FID, escalating costs with changing inlet conditions and composition.

In the EPCM (reimbursable construction) environment the major contractor tends to give less scrutiny to the FEED package, which remains the responsibility of the Owner, as all further changes are reimbursable and thus income generating. For a lump sum EPC contract the contractor needs to take ownership of the FEED package at the outset.

\section{12 Contractor Profit \& Risk}

It is understood that many major contractors did not realise their expected profit margins on lump sum EPC projects in the period 2005-2008 due mainly to increasing costs and highly competitive bidding ${ }^{17}$. As a result they moved from the lump sum EPC contract model to EPCM where the construction management is included in the lump sum but the actual cost of construction is reimbursable. The reason was to eliminate the risk due to rapidly escalating construction costs in high cost areas like Australia.

There are currently 7 major world scale LNG plant EPC contractors worldwide, which ensures competitive bidding. Further, other contractors are looking to enter this market, including WorleyParsons which has just been awarded the FEED for the Vladivostok liquefaction plant and Black \& Veatch which is offering larger 1.5 mtpa plants using electric motor drives. This would further increase competition and this is discussed later under areas for possible cost reduction.

In addition, further competition is now coming into the market from the suppliers of floating storage and regasification units (FSRUs) such as Excelerate Energy and EXMAR. These companies are offering inshore barge mounted liquefaction units at much lower costs than onshore facilities. The EXMAR barge for Pacifica Rubiales in Columbia is small at only $0.5 \mathrm{mtpa}$ and is being constructed in China at a quoted metric of $\$ 700 / \mathrm{tpa}$, which is very low when compared with traditional onshore plants.

The proposed Excelerate Energy barge for Port Lavaca is larger at $4 \mathrm{mtpa}$ and more closely resembles an onshore plant capacity. It will be built in Korea and has been quoted at a cost of $\$ 600 /$ tpa. Please note these are inshore rather than offshore units and they are essentially onshore plants built on a barge in a shipyard with lower unit costs. Storage is provided in the hull and the export tanker comes alongside for loading.

For deeper water gas field monetisation Shell is currently constructing its Prelude floating liquefaction vessel to produce $3.6 \mathrm{mtpa}$ in the Timor Sea and Petronas is constructing its Kanowit vessel to produce $1.2 \mathrm{mtpa}$ offshore Sarawak. A second vessel for Petronas is about to be awarded. This

\footnotetext{
${ }^{17}$ Confidential discussions with major contractors. The impact of rising costs is specifically mentioned in Chiyoda Annual Report 2005 http://www.chiyoda-corp.com/ir/library/file/annual-report/AR05.pdf
} 
competing technology provides further competition by bringing new contractors (the shipyards) into the market.

\section{13 Currency Exchange Risk}

Currency exchange costs have been quoted as a significant contributor to the increased project costs in Australia and PNG. The Australian dollar has risen by 20\% against the US dollar since 2009 and this is significant as typically $50 \%$ of the project costs (mainly construction) are in local currency. The strengthening of the Australian dollar since 2004 is shown in Figure 15.

Chevron has stated that this increase in the Australian dollar will account for at least one-third of the $\$ 9$ billion increase in costs - a currency increase of $\$ 3$ billion in a $\$ 48$ billion project, representing an increase of $6 \%$ for currency exchange ${ }^{18}$.

Exxon has stated that foreign exchange was the single biggest cause of the cost increase of $\$ 1.4$ billion at PNG LNG where the kina has risen $20 \%$ against the US dollar. The kina is tied closely to the Australian dollar ${ }^{19}$.

\section{Figure 15: AUD vs. USD since 2003}

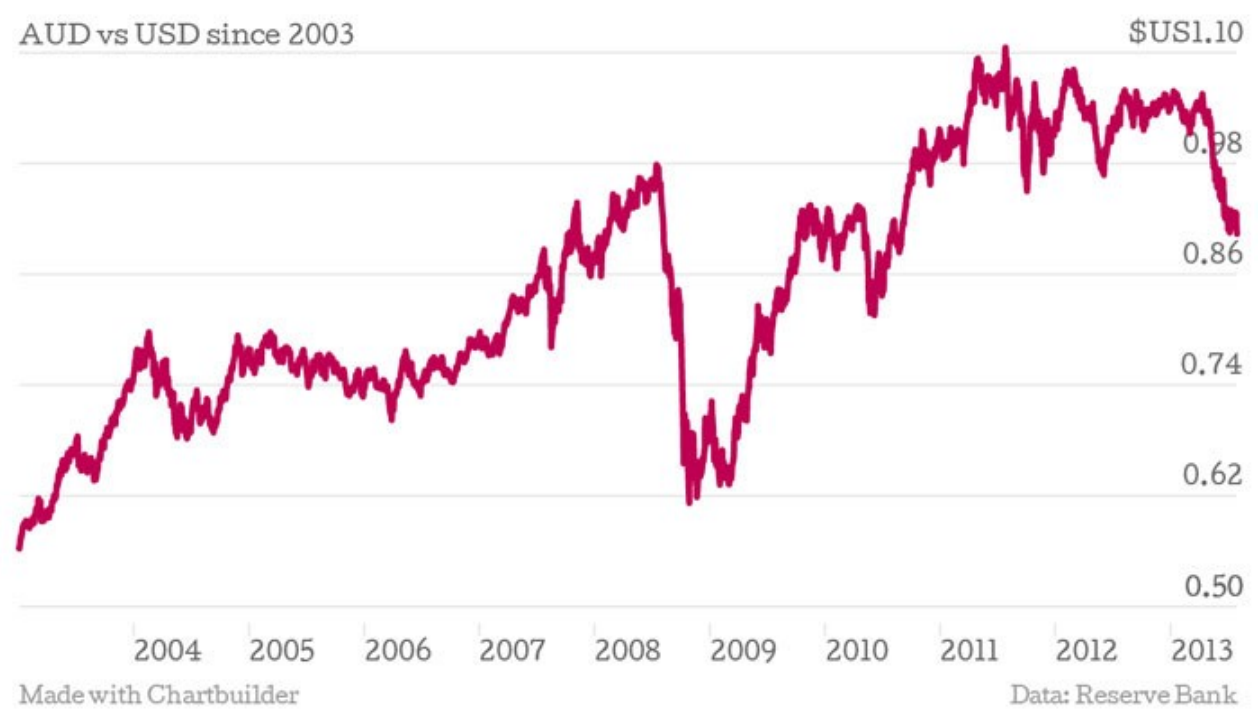

Source: Reserve Bank of Australia

http://designbuildsource.com.au/high-australian-dollar-resources

http://refinerynews.com/exxons-png-Ing-project-costs-balloon-to-19-billion/ 


\section{Chapter 5}

\subsection{Analysis of Costs}

LNG plant cost data was collected for the world scale liquefaction plants built since 1965 from published information and reports, industry contacts and other industry sources, including the author's own data base. The metric cost of $\$$ tpa was calculated and the results plotted (dotted line) as shown in Figure 16. The cost curve as shown in Figure 2 was overlaid (solid line) showing good alignment with the cost data.

Figure 16: Liquefaction Plant Metric Cost

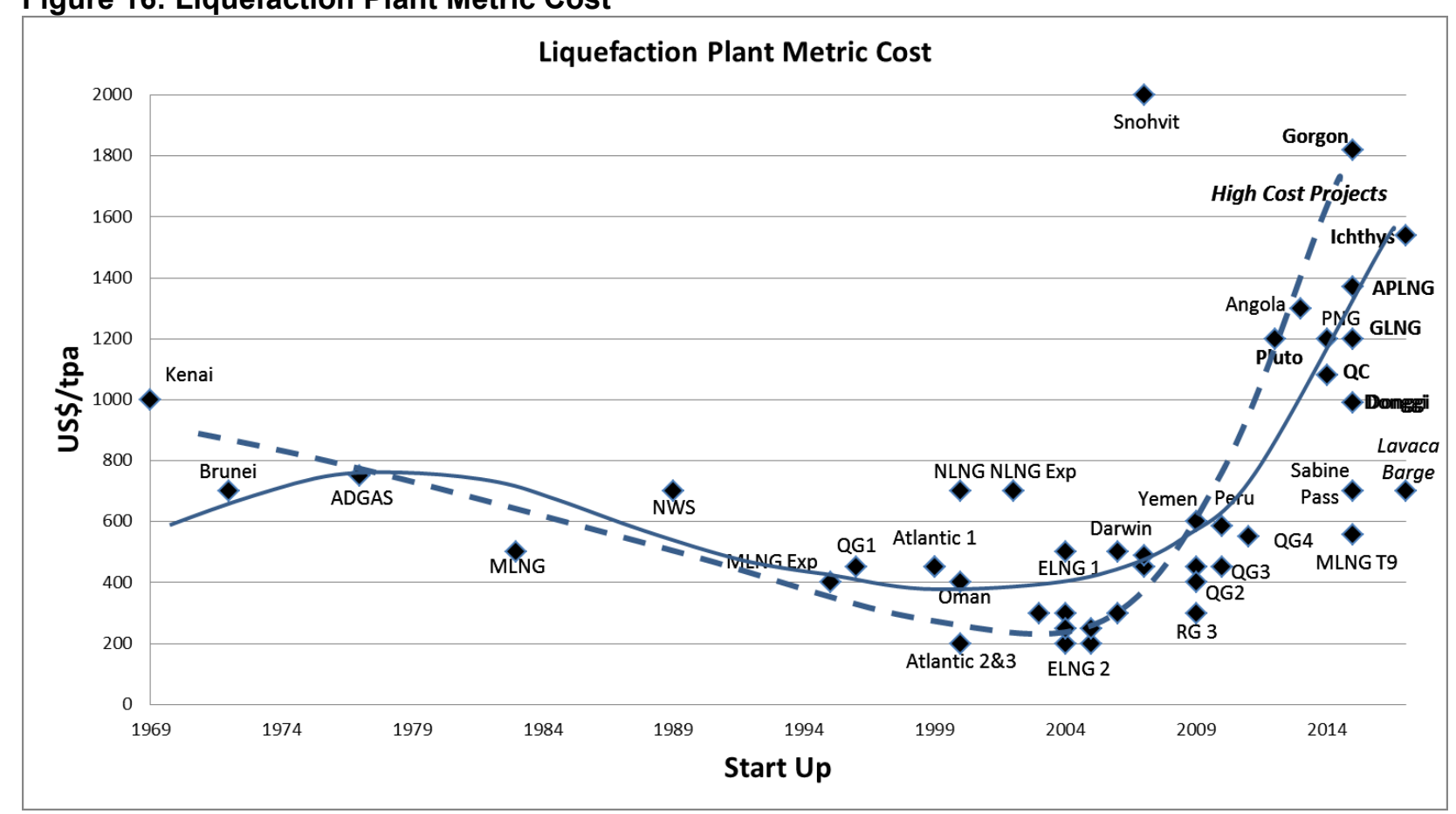

Source: Author

\subsubsection{Plant Scope - Expansion vs. Complete Facility (Grass Roots)}

The next step of the analysis was to classify the costs by scope to try and compare the projects on a like for like basis. As stated earlier, the physical scope of the plant is a major cost driver and projects vary enormously. Figure 17 divides the plants into two major groups - the expansions where just a liquefaction train or trains were installed and those comprising a complete LNG plant facility, including the process plant, storage, jetty and utilities. 
Figure 17: Liquefaction Plant Metric Cost Excluding High Cost Locations

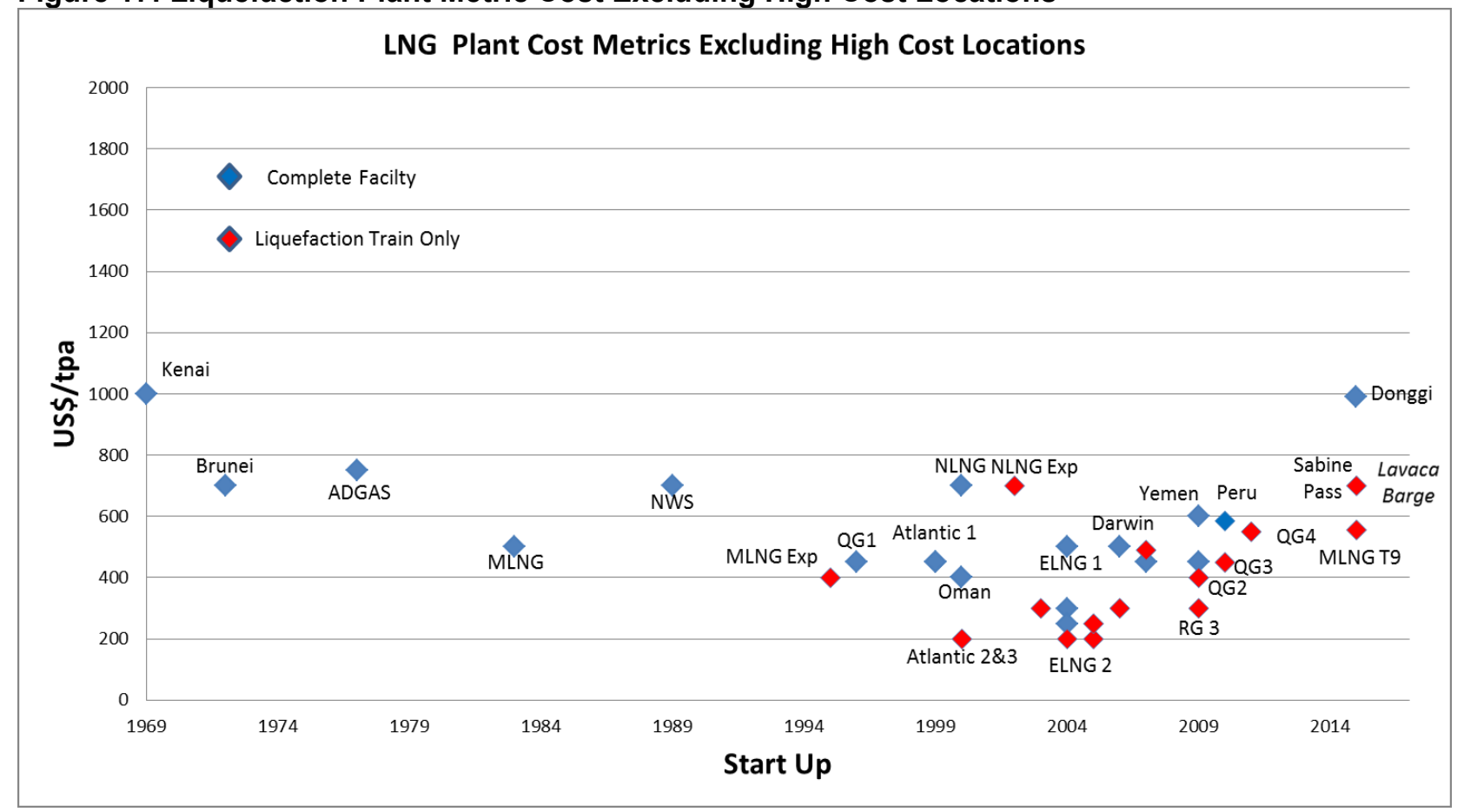

Source: Author

Until 1995 all liquefaction plants were new 'grass roots' facilities. The first expansion was undertaken at the Malaysian LNG plant in 1995 and the cost was lower than the original grass roots plant, as would be expected. The expansions since then, as shown by the red diamonds, are all at a lower cost due to their reduced scope. Analysis of past projects indicates that the liquefaction train only represents $66 \%$ of a complete grass roots facility or, put another way, the addition of the storage, jetty and utilities adds a further $50 \%$ to the base liquefaction plant cost.

\subsubsection{Location}

Figure 18 circles all the recent high cost projects with the exception of Snøhvit and they are all located in Australia and PNG, with the exception of Angola. 
Figure 18: High Cost Project Group

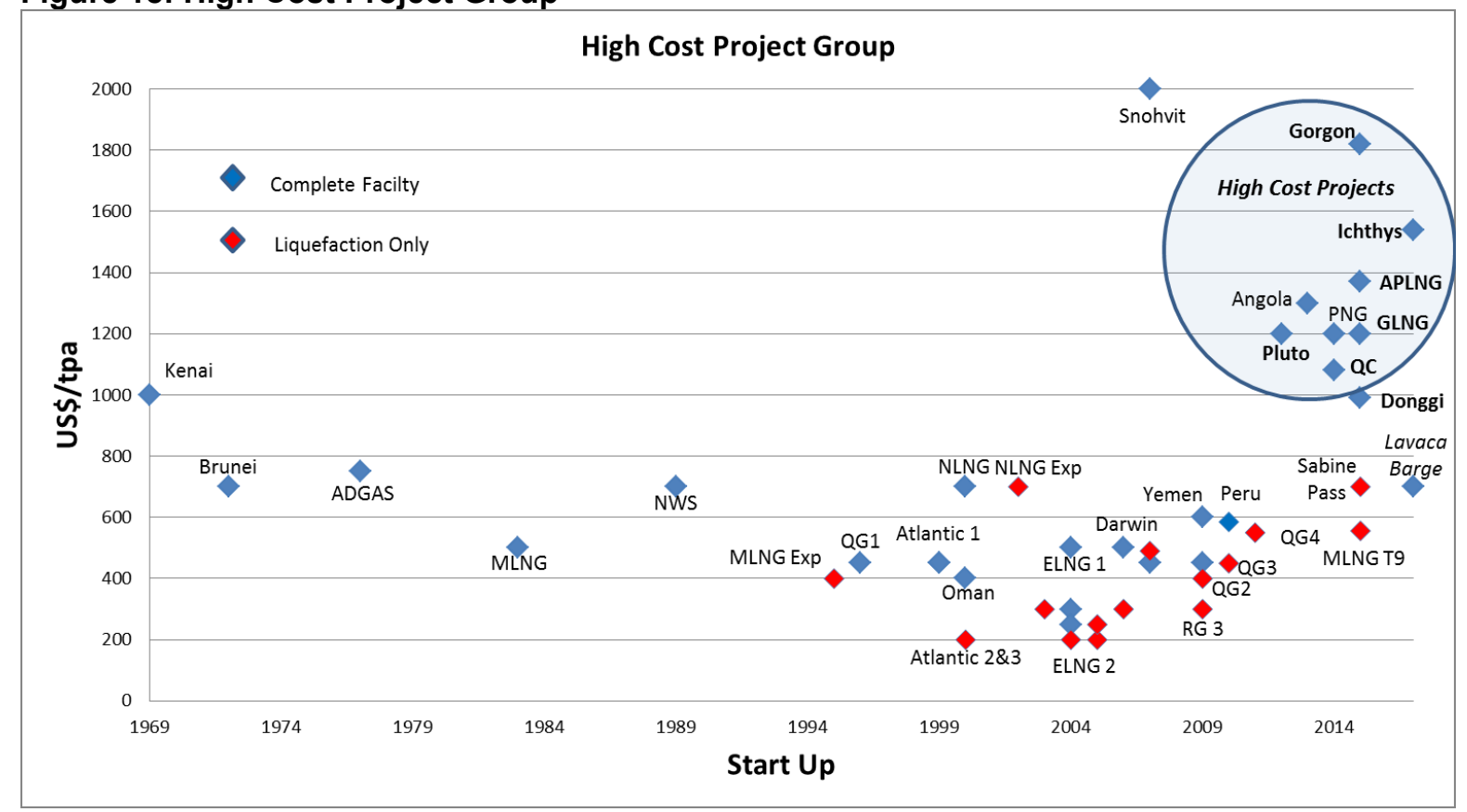

Source: Author

Regarding the Australian projects, these exceptionally high costs reflect the very complex nature of the projects, their remote location and their being built where construction costs are regarded as some of the highest in the world. The same is true for PNG where costs are similar to Australia and the project is complex with local land ownership and workforce issues and a remote location with limited infrastructure.

As an example, the cost of a welder in Australia has been quoted at $A \$ 250,000 /$ year, which is double the cost of a similar welder in Qatar, Singapore or the USA ${ }^{20}$. Similarly, LNG tanks recently constructed in Australia cost twice as much as the same tanks recently built in Singapore ${ }^{21}$.

Most Australian LNG projects have exceeded their original budget by $30 \%$. Gorgon has recently cancelled its expansion and Browse has moved from an onshore plant to a floating barge.

The Snøhvit project at $\$ 2,000 /$ tpa is regarded as very complex, located on a remote island in Northern Norway and using a new liquefaction process. This was very much a unique project and much has been reported in the LNG press about the challenges that the project faced ${ }^{22}$.

The Angola project has its own particular problems and suffered significant delays, adding to the cost. Care needs to be taken with estimating the cost of the proposed projects in Mozambique and Tanzania and any applicable learning from Angola should be applied.

\footnotetext{
${ }^{20}$ http://business.financialpost.com/2013/09/18/canada-Ing/? Isa=ffec-dfc5

${ }^{21}$ Confidential discussion with major LNG tank supplier and confidential project cost data

${ }^{22}$ http://www.statoil.com/en/OurOperations/ExplorationProd/ncs/Pages/SnohvitNewEnergyHistorylnTheNorth.aspx, http://www.ivt.ntnu.no/ept/fag/tep4215/innhold/LNG\%20Conferences/2005/SDS TIF/050123PR.pdf
} 


\subsubsection{Trends Excluding the High Cost Projects}

If the high cost projects (mostly Australian) are excluded, as shown in Figure 19, and the current expected outturn costs for Sabine Pass, Malaysian LNG Train 9 and Donggi (which are all under construction) are included, then the cost increase of $120 \%$ over the period $2000-2012$ is more in line with escalation in the upstream oil and gas industry, as reported by the $\mathrm{UCCl}$ index and referred to in chapter 1 (figure 3 ). The red line indicates the trend for process trains only and the blue line for the complete facility on the basis of being $50 \%$ higher than the stand alone process train.

These trends would indicate a current cost metric of $\$ 800 /$ tpa for liquefaction trains only and $\$ 1200 /$ tpa for complete facilities.

Figure 19: Cost Trends - Additional Train vs. Grass Roots (excluding high cost projects)

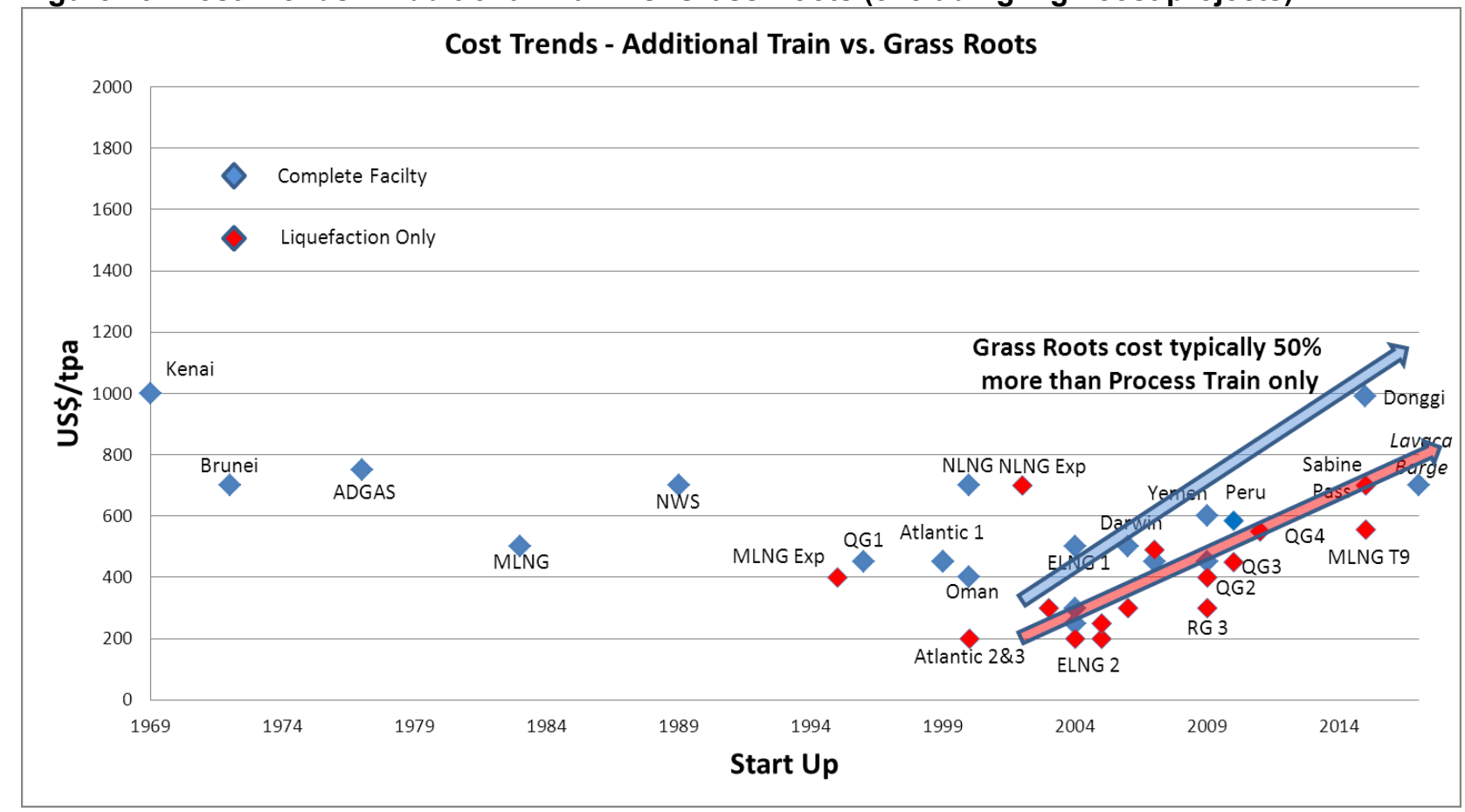

Source: Author

\subsubsection{High Cost and Normal Cost Projects}

Hence the costs can be divided into 2 groupings as shown in figure 20 - high cost projects and normal cost projects. 
Figure 20: Two Cost Groups - High Cost \& Normal Cost

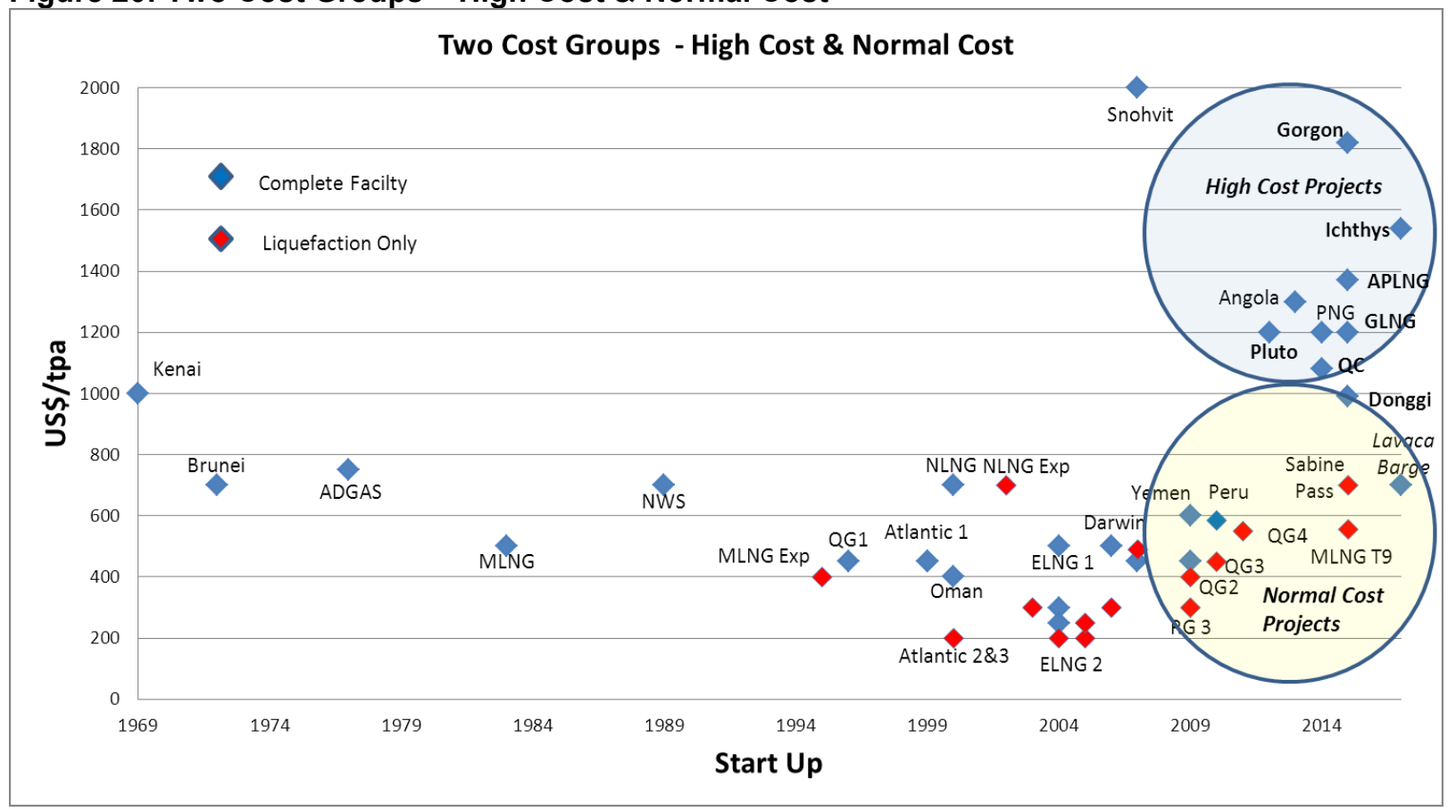

Source: Author

High cost projects are those which are located in remote areas, are complex and have a high construction cost base due to their location and the high competition for in-country resources. The principal example is Australia where 7 projects are under construction at the same time in a country with limited personnel resources and which does not allow major use of foreign construction workers.

Normal cost projects are those which are typically located in industrialised areas with good infrastructure and easy access to competitively priced construction resources. Examples include Qatar, where 4 major liquefaction units were recently constructed, and the US Gulf Coast where the Sabine Pass plant is under construction.

Hence estimating the costs for planned projects will be highly dependent on the location and will favour the low cost industrial areas, for example the USA, over Australia.

The very high costs currently being experienced in Australia have put a hold on new projects and expansions, including:

Shelving of train 4 for Gorgon

Move of Browse from onshore to floating LNG to reduce in-country costs

Arrow project likely to be merged with existing development

Scarborough offshore field likely to be developed as a floating LNG facility

Shelving of Pluto phase 2

The Australian situation was recently summarised by ANZ Research in its April 2013 'Australian Major Project Update' which stated 'the possible next wave of LNG investment in Australia faces a variety of challenges related to escalating labour costs, the high Australian dollar and the potential competitive threat of $L N G$ exports from the United States. As a result, there is now only a very small likelihood of further onshore greenfield LNG developments being commissioned. We expect that 
companies will instead prefer to expand existing LNG facilities as well as employ more cost effective FLNG technology for offshore LNG developments. ${ }^{23}$

This impact is shown in figure 21.

Figure 21: Major Australian LNG Projects

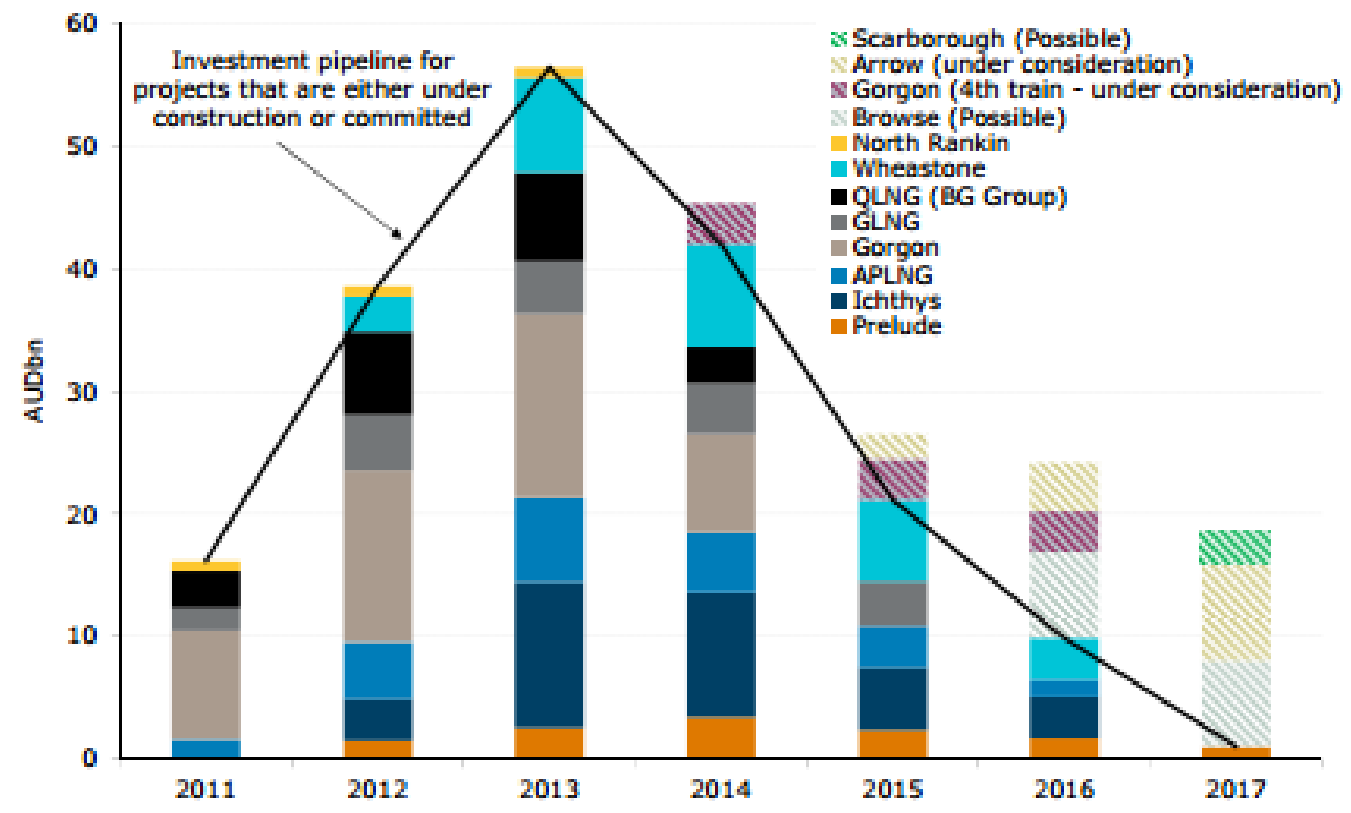

Sources: Access Economics, BREE, company reports, ANZ

Sources: Access Economics, BREE, company reports, ANZ

\subsection{Summary}

The continuous line drawn through the Australian and PNG plants in Figure 16 is not an accurate representation of cost trends for future predictions for all locations as it ignores the expected much lower outturn costs for Sabine Pass, USA, Malaysian LNG Train 9 and Donggi, Indonesia, which are also under construction. The group of inherently high cost projects is unique to Australia and PNG and other locations that are complex and have very high cost bases.

The projected costs for Sabine Pass, Malaysian LNG Train 9 and Donggi are far more in line with normal upstream oil and gas plant as recently reported, as shown on figure 20.

This will favour future LNG plant projects being located in the USA to take advantage of the lower cost base and the availability of lower cost shale gas production.

Projects in other proposed locations, for example Yamal in Siberia, Mozambique and Tanzania and Canada (British Columbia) are likely to be closer to the higher cost base due to their location and complexity. 


\section{Chapter 6}

\subsection{Areas for Future Plant Cost Reductions}

The following are areas in which the cost of LNG plants could be reduced

Using barge-mounted liquefaction plant built in a shipyard/module yard in China or Korea to take advantage of the lower cost base and higher productivity. The barge can be moored or even grounded at the location proposed for the onshore plant. This approach is currently being used for the construction of the Pacific Rubiales facility inshore Colombia and is proposed for Port Lavaca in Texas. The cost of this concept has been quoted at $\$ 700 /$ tpa including storage - considerably less than an onshore facility.

Use of alternative liquefaction processes and new EPC contractors. An example could be using the Black \& Veatch PRICO process and using Chinese construction. There are many PRICO plants operating in China and built by Chinese contractors which could be offered elsewhere, such as Mozambique and Tanzania. The PRICO process is optimised for smaller production at around 1.2-1.5 mtpa but higher capacity could be provided as multiple units.

Bringing in a competitor to GE/Nuovo Pignone who currently have the exclusive position of supplying the refrigeration compressors and drivers. Other major vendors include Siemens and Dresser for the compressors and Rolls Royce for the gas turbine drivers. All are very keen to enter this market. The increasing use of aero-derivative gas turbines as opposed to the traditional industrial gas turbines will favour Rolls-Royce with their larger Trent machines. These alternative vendors are being seriously considered for LNG concepts and this may break the trend.

Cooperation between the owners of different projects in the same area to take advantage of synergies and shared use of facilities. This is now being applied in Mozambique where Anadarko and ENI are planning a joint development. This was not the case in Queensland where completely independent plants are being built side by side, although there is some discussion now on cooperation in the gas gathering facilities.

Reconsider the use of expensive design competitions (multiple FEEDs) which require high cost multiple client teams and payment of multiple contractors with very little perceived value. Consider reverting to the original process of a single FEED as the basis for EPC bids or even the approach of using a preferred EPC contractor from the outset, which offers the lowest client team cost and probably the shortest schedule.

It is worthy of mention that the projected costs of the liquefaction plants being built in Texas and Louisiana are approximately $\$ 700 /$ tpa compared to $\$ 1400 /$ tpa in Australia i.e. half the cost. This, coupled with the low cost of gas in the USA will present Australia and other high cost areas with a major challenge and needs to be addressed if further projects are to be developed in those areas. 


\section{Chapter 7}

\subsection{Summary \& Conclusions}

LNG plant costs are expressed as a metric cost of US\$/tpa. Whilst this is a simple tool for comparison, it can be very misleading as no two plants are ever created with the same scope, location and complexity.

Plant scope, as typically measured by equipment count, can increase by a factor of 4 from a simple base liquefaction train to a complete facility including storage, utilities and export jetty. Cost can further increase with the addition of infrastructure such as a construction camp, township and airstrip. In the case of the coal bed methane projects in Queensland, the cost of the gas gathering system has been stated to be equal to that of the plant facilities, which doubles the project cost.

The very high cost of the current Australian projects is unique to that location and driven by a strengthening Australian dollar against the US dollar, the very high construction costs (which have been quoted as high as 2-3 times that of USA Gulf Coast costs) and the remote locations, far from any major infrastructure.

The high Australian plant costs are not reflected in the plants currently under construction in the USA, Malaysia and Indonesia. The increases in USA, Malaysian and Indonesian plants reflect cost increases over the $2005-2012$ period of approximately $100 \%$ and similar to those experienced in the upstream oil and gas industry generally and not the $200 \%$ experienced for the Australian projects. This rapid rise in Australian costs has led to future projects being shelved or consideration being given to floating LNG facilities that can be fabricated at a lower cost location such as Korea and China.

An example of this move towards floating liquefaction is the recent decision by Woodside and its partners on the Browse project to move to FLNG on the basis of lower cost. Inshore floating liquefaction plants are also a possibility, as proposed for Port Lavaca, Texas where the LNG barge cost appears cheaper than the onshore Sabine Pass project. An inshore barge is also under construction by EXMAR for the Pacific Rubiales project in Colombia where the cost has been stated as $\$ 700 /$ tpa which is similar to that quoted for Port Lavaca. A second EXMAR unit is being considered for British Columbia, Canada.

LNG plant metric costs are essentially driven by two major factors - the scope (liquefaction only or a complete facility) and the location where local costs are the major driver. Figure 22 shows the cost patterns diagrammatically. 
Figure 22: Liquefaction Plant Metric Cost Patterns

\begin{tabular}{|c|c|c|c|}
\hline \multirow{2}{*}{ 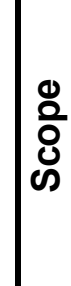 } & $\begin{array}{l}\text { Complete } \\
\text { Facility }\end{array}$ & High & High High \\
\hline & $\begin{array}{c}\text { Liquefaction } \\
\text { Only }\end{array}$ & Low & High \\
\hline & & Normal Cost & High Cost \\
\hline & & & \\
\hline
\end{tabular}

Source: Author

Typical current metric costs for these four groups are summarised in Figure 23.

Figure 23: Liquefaction Plant Metric Costs

\begin{tabular}{|c|c|c|}
\hline $\begin{array}{c}\text { Complete } \\
\text { Facility }\end{array}$ & US\$1000-1200/tpa & US $\$ 1400-1800 /$ tpa \\
\cline { 2 - 3 } $\begin{array}{c}\text { Liquefaction } \\
\text { Only }\end{array}$ & US\$600-800/tpa & US\$1000-1200/tpa \\
\cline { 2 - 3 } & Normal Cost & High Cost \\
\hline
\end{tabular}

Source: Author

The typical metric costs given in Figure 23 are indicative only. A cost estimate must be prepared to address the specifics of each project as 'no two plants are ever created equal.'

In summary, the following opportunities exist for reducing plant costs:

Barge mounted plant built in a shipyard

Using alternate processes and EPC contractors

Bringing in competition to $\mathrm{GE}$ for the refrigeration compressors and their drivers

Utilising the synergies between projects located adjacent to each other and sharing common facilities

Simpler contracting strategies to reduce the number of contracts

None of these represents a 'silver bullet' which will radically reduce liquefaction costs overnight. Whilst we might have reasonable expectations that these might work to the advantage of US LNG export projects, in other key locations such as East Africa, Canada and the Russian Arctic factors such as the lack of existing infrastructure, availability of skilled labour and in some cases specific locational challenges might be expected to maintain upward pressure on costs. 


\section{Appendix 1 World Scale Liquefaction Plants}

\begin{tabular}{|c|c|c|c|c|c|}
\hline Name & Country & $\begin{array}{c}\text { Number } \\
\text { of } \\
\text { Trains }\end{array}$ & $\begin{array}{c}\text { Train Capacity } \\
\text { mtpa }\end{array}$ & $\begin{array}{c}\text { Total } \\
\text { Production } \\
\text { mtpa }\end{array}$ & Start-up \\
\hline \multicolumn{6}{|l|}{ On-Stream } \\
\hline Kenai & Alaska, USA & 1 & 1.0 & 1.0 & 1969 \\
\hline Brunei & Brunei & 4 & 1.1 & 4.4 & 1972 \\
\hline Skikda & Algeria & 1 & 4.0 & 4.0 & 1972 \\
\hline Brunei & Brunei & 1 & 2.1 & 2.1 & 1974 \\
\hline ADGAS 1 & UAE & 2 & 1.1 & 2.2 & 1977 \\
\hline Bontang I Trains A,B & Indonesia & 2 & 1.8 & 3.6 & 1977 \\
\hline Arun I & Indonesia & 2 & 1.7 & 3.4 & 1978 \\
\hline Arzew GL1Z & Algeria & 6 & 1.4 & 8.4 & 1978 \\
\hline Skikda GL2K & Algeria & 6 & 1.3 & 7.8 & 1981 \\
\hline Arzew GL2Z & Algeria & 6 & 1.3 & 7.8 & 1982 \\
\hline Bontang II Trains C,D & Indonesia & 2 & 2.3 & 4.6 & 1983 \\
\hline MLNG Bintulu I Satu & Malaysia & 3 & 2.0 & 6.0 & 1983 \\
\hline Arun II & Indonesia & 2 & 2.2 & 4.4 & 1984 \\
\hline Arun III & Indonesia & 1 & 2.5 & 2.5 & 1986 \\
\hline Bontang III Train E & Indonesia & 1 & 2.9 & 2.9 & 1989 \\
\hline North West Shelf $1 \& 2$ & Australia & 2 & 2.1 & 4.2 & 1989 \\
\hline Arzew I \& II & Algeria & 2 & 2.6 & 5.2 & 1990 \\
\hline North West Shelf 3 & Australia & 1 & 2.1 & 2.1 & 1993 \\
\hline ADGAS 2 & UAE & 1 & 1.3 & 1.3 & 1994 \\
\hline Bontang IV - Train F & Indonesia & 1 & 2.9 & 2.9 & 1994 \\
\hline MLNG Bintulu 2 Dua & Malaysia & 3 & 2.6 & 7.8 & 1995 \\
\hline Arzew & Algeria & 6 & 1.6 & 9.6 & 1996 \\
\hline Qatargas I Trains 1,2,3 & Qatar & 3 & 2.0 & 6.0 & 1996 \\
\hline Bontang V - Train G & Indonesia & 1 & 2.7 & 2.7 & 1998 \\
\hline Atlantic I & Trinidad and Tobago & 1 & 3.1 & 3.1 & 1999 \\
\hline Bontang VI - Train $\mathrm{H}$ & Indonesia & 1 & 3.0 & 3.0 & 1999 \\
\hline RasGas I - Trains 1,2 & Qatar & 2 & 3.3 & 6.6 & 1999 \\
\hline Nigeria LNG $1 \& 2$ & Nigeria & 2 & 3.0 & 6.0 & 2000 \\
\hline Oman Trains 1,2 & Oman & 2 & 3.3 & 6.6 & 2000 \\
\hline Atlantic $2 \& 3$ & Trinidad and Tobago & 2 & 3.4 & 6.8 & 2002 \\
\hline Nigeria LNG 3 & Nigeria & 1 & 3.0 & 3.0 & 2002 \\
\hline MLNG Bintulu 3 Tiga & Malaysia & 2 & 3.4 & 6.8 & 2003 \\
\hline RasGas II - Train 3,4,5 & Qatar & 3 & 4.7 & 14.1 & 2004 \\
\hline Damietta & Egypt & 1 & 5.0 & 5.0 & 2005 \\
\hline Egypt LNG I \& II & Egypt & 2 & 3.6 & 7.2 & 2005 \\
\hline
\end{tabular}




\begin{tabular}{|c|c|c|c|c|c|}
\hline Name & Country & $\begin{array}{l}\text { Number } \\
\text { Trains }\end{array}$ & $\begin{array}{c}\text { Train Capacity } \\
\text { mtpa }\end{array}$ & $\begin{array}{c}\text { Total } \\
\text { Production } \\
\text { mtpa }\end{array}$ & Start-up \\
\hline Atlantic 4 & Trinidad and Tobago & 1 & 3.3 & 3.3 & 2006 \\
\hline Darwin & Australia & 1 & 3.5 & 3.5 & 2006 \\
\hline Nigeria LNG 4 \& 5 & Nigeria & 2 & 4.1 & 8.2 & 2006 \\
\hline Qalhat Train 3 & Oman & 1 & 3.3 & 3.3 & 2006 \\
\hline EG LNG Trains 1,2 & Equatorial Guinea & 2 & 3.4 & 6.8 & 2007 \\
\hline Snohvit & Norway & 1 & 4.2 & 4.2 & 2007 \\
\hline Nigeria LNG 6 & Nigeria & 1 & 4.1 & 4.1 & 2008 \\
\hline North West Shelf Train 5 & Australia & 1 & 4.4 & 4.4 & 2008 \\
\hline Yemen & Yemen & 1 & 3.6 & 3.6 & 2008 \\
\hline Qatargas II Trains 4,5 & Qatar & 2 & 7.8 & 15.6 & 2009 \\
\hline RasGas III - Trains 6,7 & Qatar & 2 & 7.8 & 15.6 & 2009 \\
\hline Sakhalin Trains 1,2 & Russia & 2 & 4.8 & 9.6 & 2009 \\
\hline Tangguh Trains 1,2 & Indonesia & 2 & 3.8 & 7.6 & 2009 \\
\hline Peru LNG & Peru & 1 & 4.5 & 4.5 & 2010 \\
\hline Qatargas III Train 6 & Qatar & 1 & 7.8 & 7.8 & 2010 \\
\hline Qatargas IVTrain 7 & Qatar & 1 & 7.8 & 7.8 & 2011 \\
\hline Pluto & Australia & 1 & 4.3 & 4.3 & 2012 \\
\hline Skikda & Algeria & 1 & 4.5 & 4.5 & 2013 \\
\hline Angola & Angola & 1 & 5.2 & 5.2 & 2013 \\
\hline \multicolumn{6}{|l|}{ Under Construction } \\
\hline PNG & Papua New Guinea & 2 & 3.4 & 6.8 & 2014 \\
\hline Australia Pacific & Australia & 2 & 3.9 & 7.8 & 2015 \\
\hline Donggi-Senoro & Indonesia & 1 & 2.0 & 2.0 & 2015 \\
\hline Gladstone & Australia & 2 & 4.5 & 9.0 & 2015 \\
\hline Gorgon & Australia & 3 & 5.0 & 15.0 & 2015 \\
\hline Petronas Floating & Malaysia & 1 & 1.2 & 1.2 & 2015 \\
\hline Sabine Pass & USA & 4 & 4.5 & 18.0 & 2015 \\
\hline Prelude Floating & Australia & 1 & 3.6 & 3.6 & 2016 \\
\hline Wheatstone & Australia & 2 & 4.3 & 8.6 & 2016 \\
\hline Ichthys & Australia & 2 & 4.2 & 8.4 & 2017 \\
\hline
\end{tabular}




\section{Glossary}

Bcfd - Billion cubic feet per day. A flowrate or production output of typically natural gas commonly used in North America.

Bcma - Billion cubic metres per annum. A flowrate or production output of natural gas commonly used internationally.

Capex - Industry term for Capital Expenditure

Coal Bed Methane - methane produced from wells drilled into coal seams allowing the methane to desorb from natural fractures (clints) in the coal and from the coal matrix after a period of de-watering. Also known as 'coal seam gas'.

EPC - Engineering, Procurement and Construction

Eng \& PM - Engineering and Project Management

FEED - Front End Engineering Design

FID - Final Investment Decision - Typically made by the investors in an LNG project when all necessary sales contracts and other government and regulatory approvals are in place.

Liquefaction - The process by which pre-treated natural gas is cooled to minus $160^{\circ}$ Celsius when it becomes a liquid at atmospheric pressure.

LNG - Liquefied Natural Gas

Metric Cost - In many instances in this paper a 'metric cost' is used to describe a measure used to compare the relative costs of different liquefaction projects.

Natural Gas Liquids - Typically the ethane, propane, butane and higher alkanes occurring within a natural gas reservoir extracted from the methane in the course of processing it to grid or liquefaction specification.

NBP - The UK gas market trading hub (virtual location)

tpa, mtpa - Tonnes per annum, Million tonnes per annum.

UCCI - Upstream Capital Cost Index 


\section{Bibliography}

ANZ (2013): Anz Research - Australian Major Project Update http://www.gladstoneregion.info/Portals/3/DOCUMENTS/Member\%20Offers/Major\%20project\%20upd ate $\% 20-$ March\%202013.pdf

Australian Reserve Bank - Exchange Rate Trends 2004-2013. http://www.rba.gov.au/statistics/histexchange-rates/

Australian Government Access Economics, Bureau of Resources \& Energy Economics, Company Reports, ANZ - Major Australian LNG Projects.

http://www.gladstoneregion.info/Portals/3/DOCUMENTS/Member\%20Offers/Major\%20project\%20upd ate\%20-March\%202013.pdf

BP (2012) - Draft LNG Plant Cost Presentation (Internal Report).

GIIGNL LNG Industry Report 2012,

http://www.giignl.org/sites/default/files/publication/giignl the Ing industry 2012.pdf

IGU World LNG Report - 2011,

http://www.igu.org/gas-knowhow/publications/igu-publications/LNG\%20Report\%202011.pdf,

IHS - CERA Upstream Capital Costs Index (UCCI)

http://www.ihs.com/info/cera/ihsindexes/index.aspx

KBR (2007) - Paper 'LNG liquefaction - Not all plants are created equal' - Authors: Heinz Kotzot Section Leader, LNG and Gas Processing, Charles Durr - Energy Technology, David Coyle Technology Manager, Chris Caswell - Principal Technical Professional, February 2007. http://www.kbr.com/newsroom/publications/technical-papers/Ing-liquefaction-not-all-plants-arecreated-equal.pdf

LNG Plant Project Photographs - Woodside Petroleum (Wheatstone), Equatorial Guinea LNG Holdings Limited ( EG LNG).

TK Uhde Energy and Power - Project Activities Schedule (Gated Process). http://www.thyssenkruppuhde-energyandpower.com/en/services/project-management.html 